\title{
Two-mica and biotite granites in the Weitra-Nové Hrady area, Austria - Czech Republic
}

\author{
Dvojslídné a biotitické granity v okolí Weitry a Nových Hradů \\ (Rakousko, Česká republika)
}

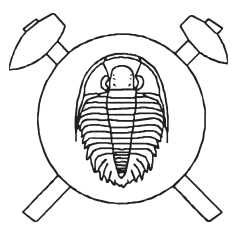

\author{
(7 figs, 3 tabs) \\ KAREL BREITER $^{1}$ - SUSANNA SCHARBERT ${ }^{2}$ \\ ${ }^{1}$ Czech Geological Survey, Geologická 6, CZ-152 00 Praha 5, Czech Republic \\ ${ }^{2}$ Geologische Bundesanstalt, Neulinggasse 38, A-1030 Wien, Austria
}

\begin{abstract}
The South Bohemian Pluton consists, in traditional view, of three major granite suites - the Weinsberg, Eisgarn, and Freistadt suites. In reality, the composition of the pluton is even more complicated than this subdivision would suggest. For instance, in the area among towns of Weitra, Freistadt and Nové Hrady, besides the clearly defined Weinsberg granite, four additional granite types have been distinguished on the basis of their field relations, petrology, whole-rock and isotope geochemistry: (1) medium-grained, locally porphyritic peraluminous two-mica Žofín granite, $324 \pm 14$ Ma old with initial $\mathrm{Sr}$ isotopic ratios $\left({ }^{87} \mathrm{Sr} /{ }^{86} \mathrm{Sr}_{\mathrm{i}}\right)$ of 0.712 ; (2) peraluminous fractionated suite of coarsegrained two-mica Mandelstein granite, accompanied by muscovite Nakolice-Pyhrabruck and Šejby granites with ${ }^{87} \mathrm{Sr} /{ }^{86} \mathrm{Sr}{ }_{i} \sim 0.706 ;(3)$ chemically primitive Karlstift biotite granite with high magnetic susceptibility and ${ }^{87} \mathrm{Sr} /{ }^{86} \mathrm{Sr}_{i}=0.706$; (4) Weitra biotite granite with a magnetic and a non-magnetic varieties followed by dykes of muscovite granite $\left({ }^{87} \mathrm{Sr} /{ }^{86} \mathrm{Sr}_{i} \sim 0.705\right)$. The evolution of the peraluminous granites towards lower $\mathrm{Sr}$ initial ratios may indicate change in the magma sources at the end of the Variscan magmatic cycle and a shift to deeper, more metaigneous material.
\end{abstract}

Key words: granite; petrology; geochemistry; geochronology; Moldanubicum

\section{Introduction}

The South Bohemian Pluton, the largest Variscan magmatic pluton of the Bohemian Massif, consists of three major suites with different sources, parental magmas, degree of fractionation and crystallisation age - Weinsberg, Eisgarn, and Mauthausen/Freistadt suites (see Waldmann 1951, Fuchs - Thiele 1968, Finger et al. 1994, Koller Klötzli 1998 and Finger - Friedl 2002 for more details concerning the evolution of the granite terminology). All of them occur at the border of Nieder- and Oberösterreich and southern Bohemia, between the towns of Weitra, Freistadt and Nové Hrady. While the metaluminous Weinsberg and Freistadt suites build relatively simple, discrete plutons, the peraluminous Eisgarn suite is much more complicated and consists of several individual intrusions. After clarifying the structure of the Eisgarn suite in its northern part (Breiter - Koller 1999, Breiter Scharbert 1995, 1998) we decided to study the southwestern part of the Eisgarn suite near Weitra, at its contact to the Weinsberg and Freistadt units.

Geological maps published by the Czech and Austrian geological surveys differ significantly in the interpretation of the internal structure of the South Bohemian Pluton in the Weitra-Nové Hrady area (Erich - Schwaighofer 1977, Fuchs - Schwaighofer 1978, Staník 1981, Slabý 1992). The "Eisgarn" type granite of the Austrian map comprises all varieties of two-mica granites while on the Czech maps the "Mrákotín" type granite and several types of coarse-grained granites are distinguished. The term "Mauthausen" has been formerly used for all the fine-grained (biotite and/or two-mica) granites through the whole Austrian Moldanubicum, which has caused much confusion. This name, and the term "Mrákotín" on the Czech side, should be in our view abandoned in the discussed area.

Klob (1970) found a new variety of porphyritic biotite granite near Karlstift, Sandl and Liebenau (termed "Karlstift type"). Unfortunately this type was not distinguished in the maps published by Erich - Schwaighofer (1977) and Fuchs - Schwaighofer (1978). Later Göd - Koller (1989) found and described the Nebelstein complex consisting of biotite, two-mica, and muscovite ore-bearing granites. Finally, Gnojek - Přichystal (1997) described at St. Martin and Karlstift two types of biotite granites differing in their magnetic properties, partly in confusion with Klob's "Karlstift" granite. Recently Humer (Humer - Finger 2002, Humer et al. 2003) defined the "Weitra granite pluton", a biotite granite, to a great extent in confusion with biotite granites of Gnojek - Přichystal (1. c.)

The two-mica "Eisgarn" granites as well as the biotite granite at St. Martin were followed by specific types of muscovite granites. Thus, the real geological structure of this part of the South Bohemian Pluton is much more complicated than was expected several years ago.

Based on systematic field and laboratory work between 1994-2000, we undertook detailed petrological and geochemical revision of the two-mica granites and also a brief revision of the adjacent biotite granites in the Austrian-Czech border area (Figs 1,2).

Marked differences in $\mathrm{Sr}$ initial ratios between studied two-mica granite samples call for definition of two new local granite types: the Žofín and Mandelstein granites. 


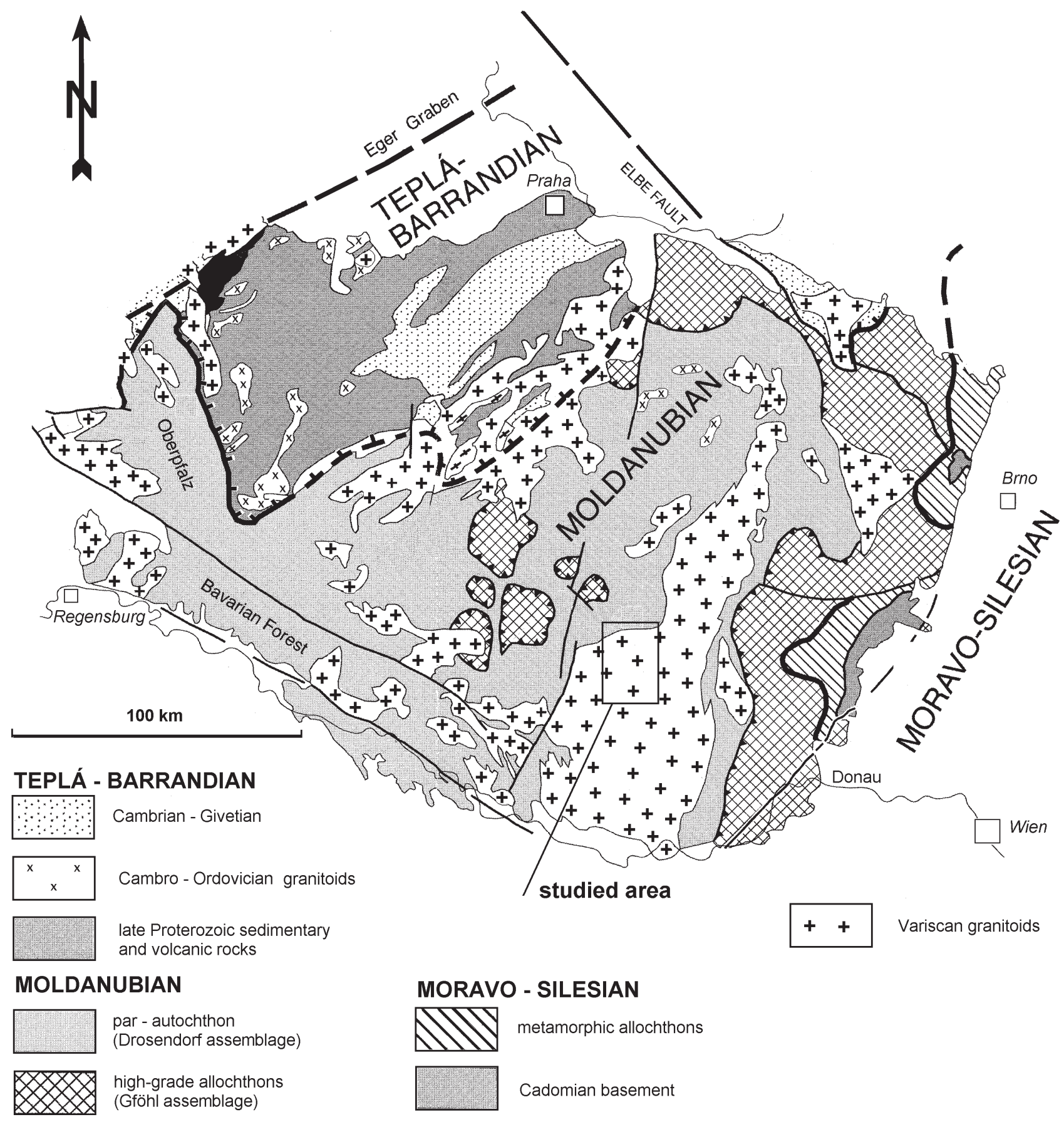

Fig. 1 Localisation of studied area (geology of the southern part of the Bohemian Massif according to Franke et al. 2000, modified).

\section{Geological mapping}

The simplified geological map of the Weitra - Nové Hrady area presented here (Fig. 2) is based on detailed field mapping on the scale 1:25 000 of the whole Eisgarn unit and brief field revision of the biotite and muscovite granites near St. Martin, Harbach and Nebelstein done between 1994 and 2000. The extent of the Karlstift granite was compiled basically from Gnojek - Přichystal (1997) with only brief field revision.

\section{Available geophysical data}

Areal geophysical measurements yield important information for compiling geological maps and for the interpretation of pluton genesis. Gamma spectrometry gives indications about the whole-rock distribution of uranium and thorium even in poorly exposed areas. Magnetometric data are very important in regions with a thick Quaternary cover.

Airborne geophysics covered the Austrian part of the studied area (Heinz - Seiberl 1990). During this measure- 


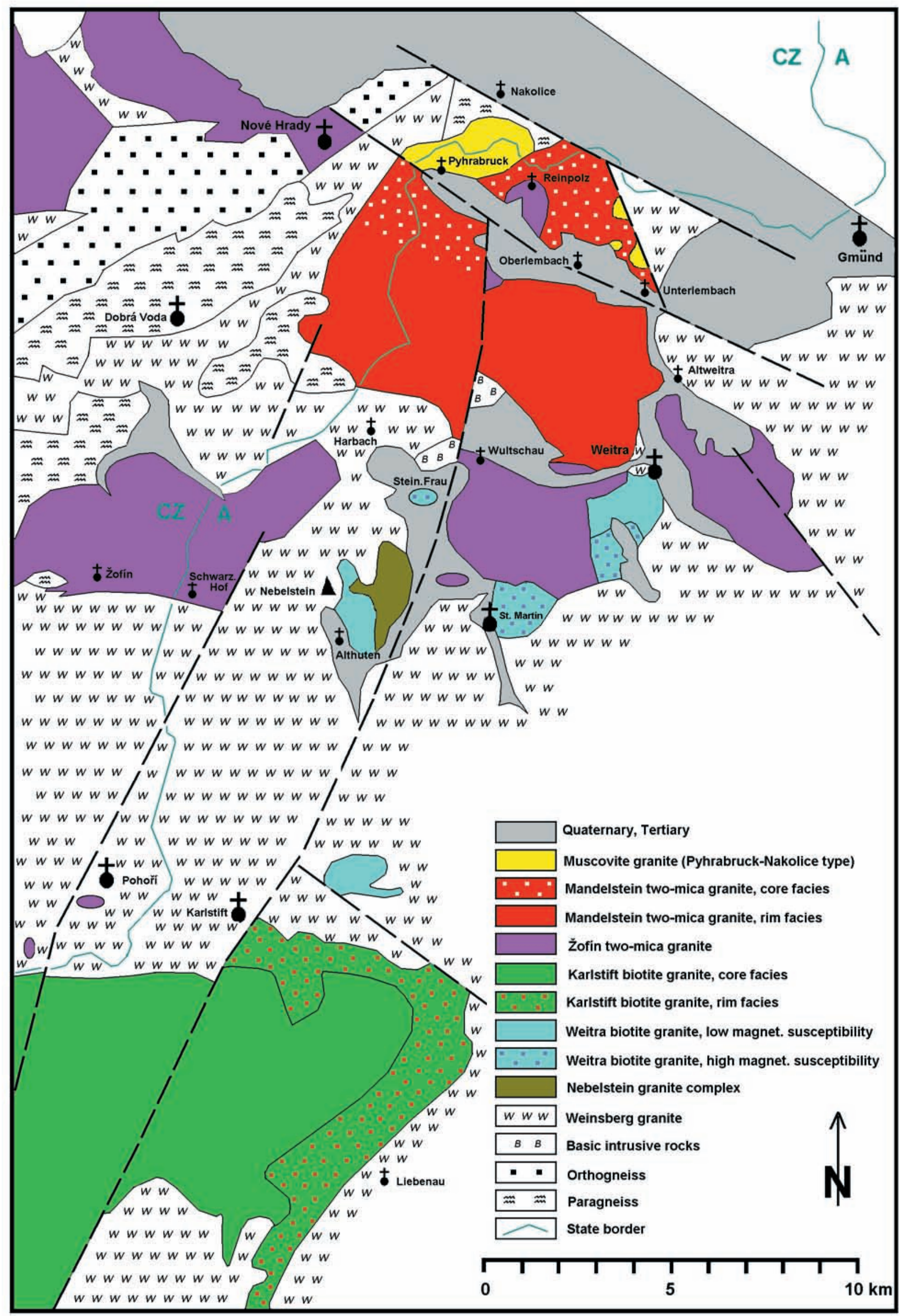

Fig. 2 Simplified geological map of studied area. Compiled from published maps amended by the fieldwork of the authors. 
ment, strong magnetic anomalies (Nebelstein, St. Martin) and radioactive anomalies (Unterlembach) were found.

In 1991-1994, the area was covered by complex spectrum of ground geophysical methods (Gnojek Prrichystal 1997) in observation point density of 8-10 points per $1 \mathrm{~km}^{2}$. Such a density of measurements allowed ascertaining the areal extent of individual rock types with characteristic properties also in areas with Quaternary cover.

Magnetic susceptibility (Fig. 3a) detected bodies of magnetite-bearing granite at St. Martin (St. Martin anomaly) and in the pericontact part of the Karlstift granite (socalled Liebenau anomaly, Göd 1989)

Gamma spectrometry found an enrichment in $U$ (Fig. 3b) in the core of the Eisgarn unit (two-mica Mandelstein granite and muscovite granites at Pyhrabruck and Unterlembach), which indicates the most fractionated parts of the pluton. In contrast, enrichment in Th (Fig. 3c) indicates the outer parts of the Eisgarn unit (the "Žofín" granite) and the pericontact part of the Karlstift granite, where Th is incorporated into accessory phases, namely monazite.

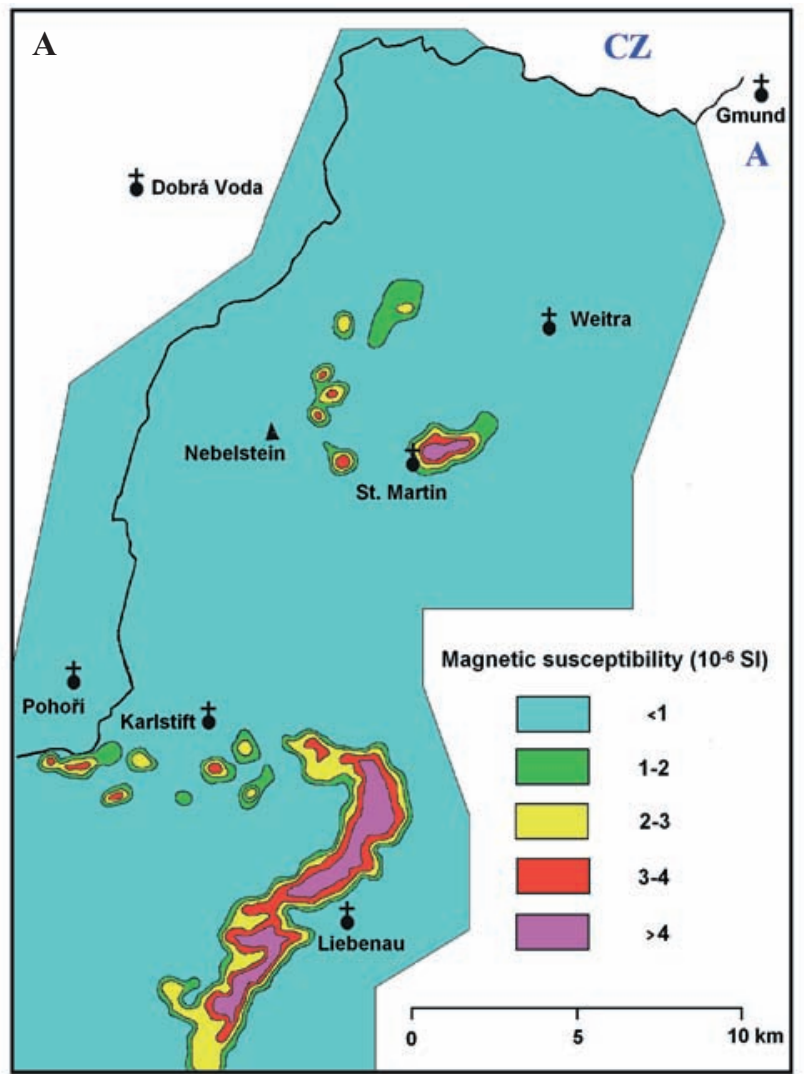

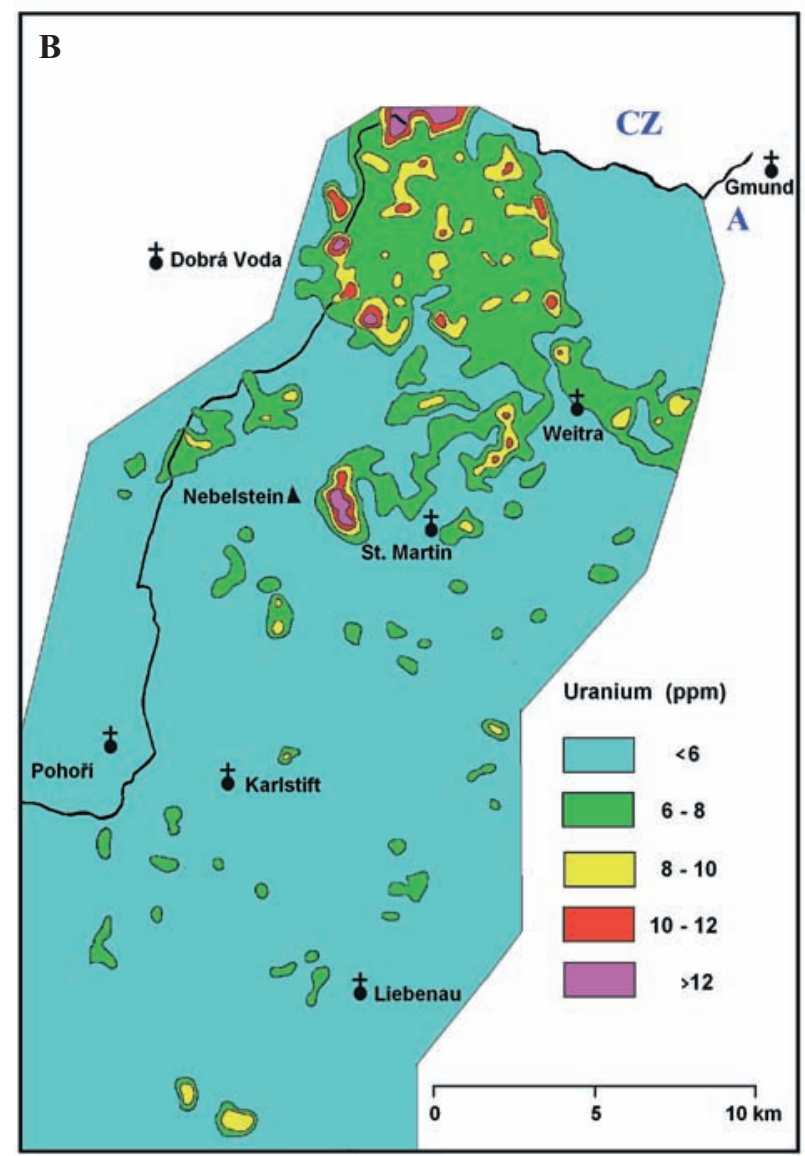

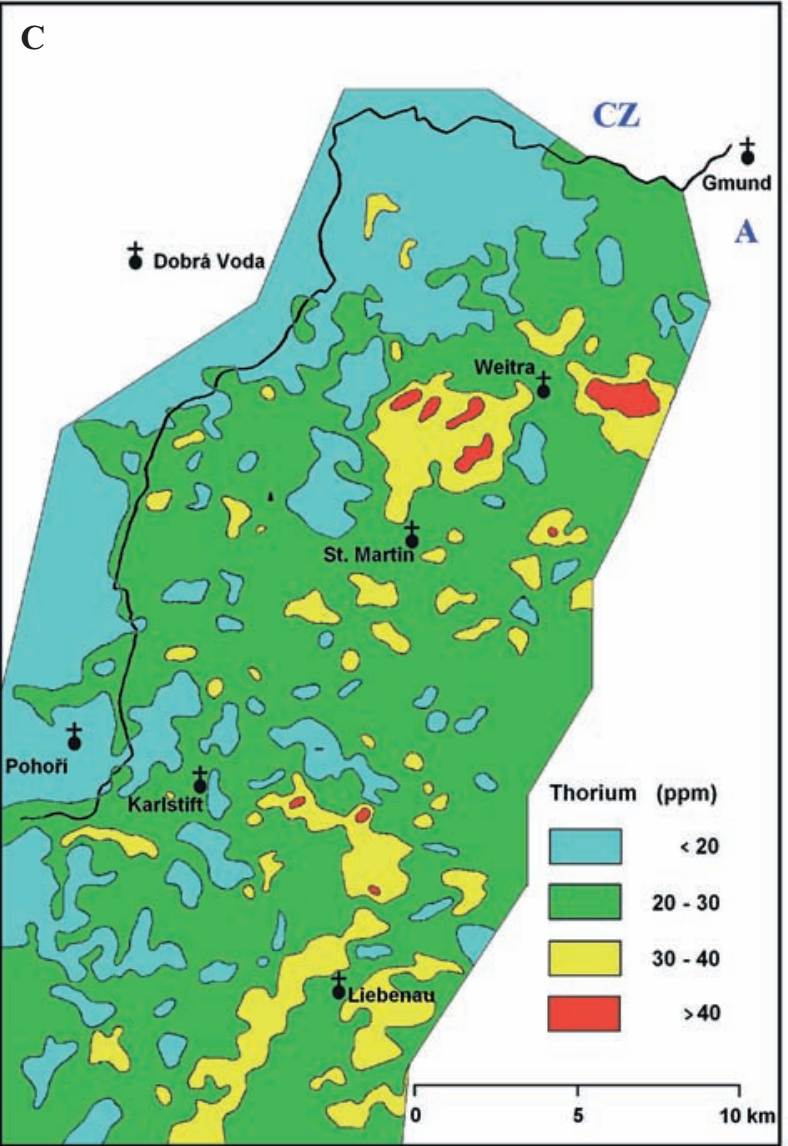

Fig. 3 Geophysical maps (simplified from Gnojek - Přichystal, 1997): A - magnetic susceptibility; B - distribution of U; C - distribution of Th, based on gamma spectrometric survey. 


\section{Description of studied granite types}

A. Peraluminous two-mica granites (the Eisgarn unit sensu lato)

Within the two-mica granites (Eisgarn unit according to Fuchs - Schweighofer 1978) we were able to distinguish two textural varieties in the field, documented also by chemical and $\mathrm{Sr}$ isotopic differences. They thus seem to represent two independent intrusions defined here as new local granite types - Žofín and Mandelstein.

1. Žofín granite - builds up the external part of the pluton, often along the contact with the biotite Weinsberg granite to the E, S and SW of Weitra. In Bohemia, identical granite appears between the Žofín settlement and Besednice (16 km to the west of Nové Hrady). The contact of this intrusion with the coarse-grained Mandelstein granite was found only rarely in blocks ENE of Wultschau. The contact here is sharp but the relative age relations are impossible to deduce. Roof pendants and giant xenoliths of fine-grained porphyritic biotite $>$ muscovite granite within the Mandelstein granite at Reinpolz NW of Weitra, which were formerly described as an independent granite type (Breiter - Scharbert 2001), should be according to our knowledge attributed to the Žofín granite and prove its older geological age. In the absence of isotopic data, we have originally used the term "Aussengranit" based on field observations.

On the published maps (sheets Weitra ÖK17 and Grosspertholz ÖK18), this granite is depicted partly as "Feinkorn" (Mauthausen) granite, partly as "Eisgarn" granite.

The Žofín granite is relatively finer grained than typical Eisgarn granite from the area $\mathrm{N}$ of Gmünd. Petrographically it resembles the granite from Mrákotín in the northern part of the South Bohemian Pluton and is chemically similar to the Č́měr̆ granite (sensu Breiter - Koller 1999). The granite is generally equigranular, only locally porphyritic (between Schwarzauer Hof and Pohorská Ves (3.5 km to the WSW of Žofín), Kfs up to $1 \mathrm{~cm})$. Biotite strongly prevails over muscovite. Small (up to $1-2 \mathrm{~cm}$ in diameter) nodules of biotite are typical. Biotite shows moderate Fe contents ( Fe/ $(\mathrm{Fe}+\mathrm{Mg}+\mathrm{Mn}+\mathrm{Ti})=0.55-0.60$, Fig. 4), plagioclase is often zoned with oligoclase core $\left(\mathrm{An}_{25-30}\right)$ and albitic rim $\left(<\mathrm{An}{ }_{10}\right)$. Phosphorus contents in plagioclase and K-feldspar are negligible. Apatite, monazite, ilmenite and zircon are the most important accessory minerals.

Fine-grained two-mica granite from the vicinity of Besednice and coarse-grained biotite granite with only traces of primary muscovite from the top of the Kohout hill near Besednice probably also belong to this granite unit. The sample from Kohout hill, together with another one from Altweitra, are very likely geochemically influenced by assimilation of the adjacent Weinsberg type granite (compare Table 3).

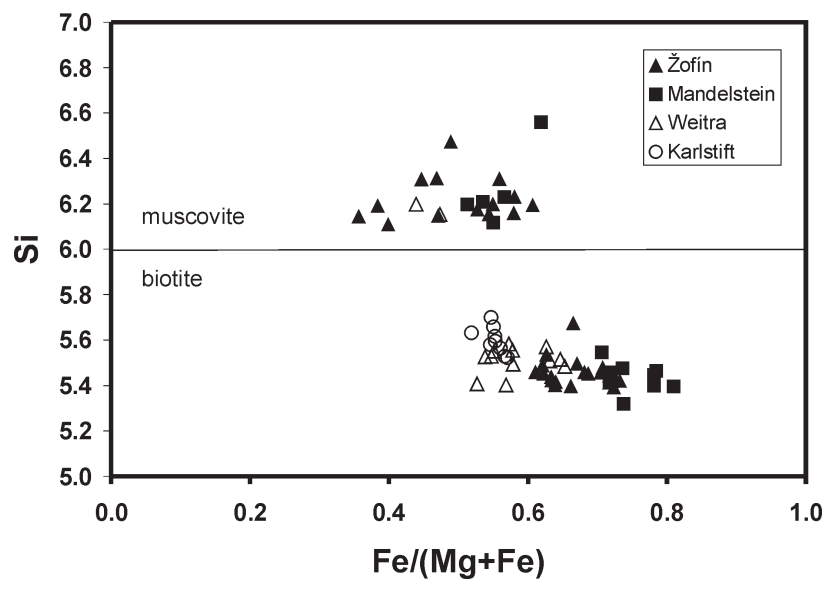

Fig. 4 Chemical composition of micas from studied rocks. Muscovites are in all cases enriched in $\mathrm{Mg}$ compared to the associated biotites. All chemical elements in atoms per formula unit.

Typical contents of $\mathrm{SiO}_{2}$ are 69-72 wt. \%, $\mathrm{MgO} 0.4$ 0.9 wt. $\% \mathrm{Fe}_{2} \mathrm{O}_{3 \text { tot }} 1.5-3.0$ wt. $\%$ and $\mathrm{CaO} 0.7-1.0$ wt. \%. Potassium clearly predominates over sodium $\left(\mathrm{K}_{2} \mathrm{O}\right.$ reacheing 5.2-5.5 wt. \% while $\mathrm{Na}_{2} \mathrm{O}$ varies only between 2.6-3.0 wt. \%).

2. Mandelstein granite is generally a coarse-grained two-mica granite, macroscopically resembling typical Eisgarn granites from the area $\mathrm{N}$ of Gmünd (Waldmann 1950). It builds the central part of the area between Weitra and Nové Hrady. Only the southern and central parts of the body are exposed. In the north the granite is covered by Cretaceous and Neogene sediments of the Třeboň basin and was reported from numerous boreholes only (Staník 1981). On the published maps (sheets Weitra and Grosspertholz), this granite is generally asssigned to the Eisgarn granite.

This granite is a truly a two-mica granite, meaning that the content of both micas is comparable. Biotite is Ferich $(\mathrm{Fe} /(\mathrm{Fe}+\mathrm{Mg}+\mathrm{Mn}+\mathrm{Ti})=0.7)$. Two types of plagioclase occur - oligoclase $\left(\sim \mathrm{An}_{20}\right)$ and pure albite. The most important accessory minerals are apatite and zircon. The Mandelstein body, similarly to the Eisgarn mass $\mathrm{N}$ of Gmünd, is chemically concentrically zoned with a less fractionated rim and more fractionated core. The core is enriched in $\mathrm{Na}, \mathrm{Rb}, \mathrm{Li}, \mathrm{F}, \mathrm{P}$, and $\mathrm{U}$. The typical contents of $\mathrm{SiO}_{2}$ reach 71-73 wt. \%, $\mathrm{MgO} 0.2-0.4$ wt. $\%, \mathrm{Fe}_{2} \mathrm{O}_{3 \text { tot }}$ $1.0-2.2$ wt. $\%, \mathrm{CaO} 0.5-0.8$ wt. $\%, \mathrm{~K}_{2} \mathrm{O} 4.5-5.0$ wt. $\%$ and $\mathrm{Na}_{2} \mathrm{O} 2.8-3.3$ wt. \%.

3. Fractionated muscovite granites are interpreted as products of crystallisation from the residual Mandelstein melt. They build small bodies at Unterlembach (Göd 1989) and Nakolice-Pyhrabruck (Breiter - Scharbert 1998). The Nakolice-Pyhrabruck granite forms a body $2 \mathrm{~km}^{2}$ in size. It is a leucocratic, medium-grained, equigranular rock consisting of quartz, pure albite, $\mathrm{K}$-feldspar and Li-muscovite. Both feldspars are enriched in phosphorus (up to 0.9 wt. $\% \mathrm{P}_{2} \mathrm{O}_{5}$ in $\mathrm{Kfs}$ ). Topaz, 
Mn-apatite, ilmenite, monazite, cassiterite and columbite occur as accessories. The typical contents of $\mathrm{SiO}_{2}$ are 74 76 wt. $\%, \mathrm{MgO}<0.05$ wt. $\%, \mathrm{Fe}_{2} \mathrm{O}_{3 \text { tot }}<1.0$ wt. $\%, \mathrm{CaO}$ $<0.5$ wt. $\%, \mathrm{~K}_{2} \mathrm{O} 3.5-4.0$ wt. $\%$ and $\mathrm{Na}_{2} \mathrm{O} 3.5-4.0$ wt. $\%$. The granite is strongly enriched in $\mathrm{P}$ (up to $0.45 \mathrm{wt} . \%$ $\mathrm{P}_{2} \mathrm{O}_{5}$ ), F (up to 0.36 wt. \%), Rb (700-800 ppm), Li (200 ppm) and Sn (20-25 ppm). The biotite-bearing facies cropping out along eastern contact of the Nakolice-Pyhrabruck body indicates presumably a gradual melt fractionation from the two-mica to muscovite granites.

The Unterlembach granite forms three small outcrops (max. $300 \mathrm{~m}$ in diameter) between villages of Unterlembach and Höhenberg. Chemically, it is poorer in $\mathrm{Rb}, \mathrm{Li}$ and $\mathrm{Sn}$, but contains up to $20 \mathrm{ppm}$ U. It contains accessory biotite and common secondary uranium minerals.

\section{B. Biotite granites and their fractionation products:}

In contrast to the aforementioned peraluminous granites, which seem to belong to a single evolutionary group, the biotite granites are much more varied. The genetic relations among individual intrusions of biotite granites are still a matter of discussion.

4. Karlstift granite sensu Klob (1970) is a fine- to medium grained biotite granite with high magnetic susceptibility and an elevated content of thorium. It crops out between the villages of Karlstift, Sandl ( $8 \mathrm{~km} \mathrm{SW}$ of Karlstift) and Liebenau. Published geological maps show different varieties of the "Feinkorngranit" (= fine-grained granite) in this area, assigning them to the Freistadt-Mauthausen suite. The "porphyritic variety" according to Fuchs - Schwaighofer (1978), cropping out near the N and NE contact, corresponds more or less to the Karlstift granite sensu Klob (1970). The inner part of the body is mostly equigranular.

The NE part of this body was newly mapped by Přichystal (Gnojek - Přichystal 1997), the SW part is less well known. Fuchs - Schwaighofer (1978) interpreted this granite as a reaction product of the Freistadt and Weinsberg units.

The major mineral phase is a zoned plagioclase. Crystals with $\mathrm{An}_{20-46}$ in the core and $\mathrm{An}_{5-30}$ in rims prevail, but also crystals with inverse zoning with albitic $\left(\mathrm{An}_{05-10}\right)$ core and more calcic rims $\left(\mathrm{An}_{20-30}\right)$ were found. Orthoclase is less abundant and strongly altered. Both feldspars are phosphorus-free. Biotite is relatively poor in $\mathrm{Fe}(\mathrm{Fe} /$ $(\mathrm{Fe}+\mathrm{Mg})=0.5-0.6)$ and contains numerous inclusions of monazite and zircon.

Typical contents of $\mathrm{SiO}_{2}$ are 67-69 wt. \%, $\mathrm{K}_{2} \mathrm{O}=3.8$ 4.5 wt. $\%, \mathrm{Na}_{2} \mathrm{O}=3.2-3.5$ wt. $\%, \mathrm{MgO}=0.8-1.3$ wt. $\%$ and $\mathrm{CaO}=2.2-3.1$ wt. \%. High concentrations of $\mathrm{Sr}(580$ $650 \mathrm{ppm})$ and Th (25-28 ppm) are characteristic of the porphyritic pericontact facies. The rock is markedly poor in $\mathrm{Rb}(150-170 \mathrm{ppm})$. The magnetic susceptibility and the contents of Ti, Ca, Fe, Sr and Th decrease towards the intrusion centre, while $\mathrm{Si}, \mathrm{K}$ and $\mathrm{Rb}$ increase slightly.
5. Fine-grained biotite granite was found in several areas near St. Martin and Nebelstein and in the town of Weitra. Humer et al. (2003) introduced the name Weitra granite. We support this name fully in areas described by Humer as "main type" facies and western facies. The area of Humer's Schützenberg facies is poorly exposed and, according to our data, its outcrops in the Lainsitz valley belong to the Žofín-type granite.

The Weitra granite comprises two macroscopically not distinguishable varieties: one with low and one with high magnetic susceptibility. The magnetic variety crops out in the centre of the St. Martin magnetic anomaly (Heinz - Seiberl 1990, Gnojek - Přichystal 1997) and at "Steinerne Frau" SE of Harbach. The non-magnetic variety was found $E$ of Nebelstein around the village of Althütten and in Weitra itself.

The magnetic variety of the Weitra granite is composed of quartz, zoned plagioclase (core $\mathrm{An}_{30}$, rim $\mathrm{An}<10$ ), perthitic orthoclase and $\mathrm{Fe}$-poor biotite $(\mathrm{Fe} /(\mathrm{Fe}+\mathrm{Mg})=0.55-$ 0.6). Common magnetite grains are associated with biotite. The non-magnetic variety is similar, only plagioclase is more albitic and magnetite is absent.

Typical major element contents are: $71-72$ wt. $\% \mathrm{SiO}_{2}$, $0.7-0.8$ wt. $\% \mathrm{MgO}, 2-3$ wt. $\% \mathrm{Fe}_{2} \mathrm{O}_{3 \text { tot }}, 1.3-2.0$ wt. $\%$ $\mathrm{CaO}, 4.5-5.0$ wt. $\% \mathrm{~K}_{2} \mathrm{O}$ and $2.8-3.1$ wt. \% (in non-magnetic variety up to 3.8 wt. \%) $\mathrm{Na}_{2} \mathrm{O}$. Characteristic features of the Weitra granite are high $\mathrm{Sr}$ (250-450 ppm) and low Rb (200-230 ppm).

6. A small body (too small to be shown on the map) of pegmatitic muscovite granite was found near the centre of the St. Martin magnetic anomaly $1 \mathrm{~km} \mathrm{NE}$ of the village. The shape of the intrusion (dyke or small stock) is uncertain. This type of muscovite granite is, in contrast to muscovite granites accompanying the Mandelstein intrusions, geochemically primitive, more enriched in silica, depleted in compatible elements, but without any enrichment of incompatible elements such as $\mathrm{F}, \mathrm{Rb}, \mathrm{Li}$ and U. Typical contents are: $\mathrm{SiO}_{2}$ up to 75 wt. $\%, \mathrm{~K}_{2} \mathrm{O}$ 4.1-4.4 wt. $\%, \mathrm{Na}_{2} \mathrm{O} 3.3-3.6$ wt. $\%, \mathrm{MgO}<0.1$ wt. $\%$ and $\mathrm{CaO}<0.5$ wt. \%. This rock is very poor in $\mathrm{Zr}(8-14$ ppm), Sr (23-49 ppm) and also in Rb (200-230 ppm), but particularly enriched in Sn (23-42 ppm).

7. Sr-rich muscovite granite forms a N-S trending, nearly $10 \mathrm{~m}$ thick dyke cutting the Mandelstein granite $\mathrm{E}$ of Oberlembach. This granite is texturally very variable, granitic parts alternate with aplitic and pegmatitic schlieren. Petrographically it resembles the pegmatitic muscovite granite from St. Martin, but differs significantly by much higher concentrations of Sr (539 ppm) and Zr (177 ppm) and lower Rb (140 ppm).

\section{Chemical characteristics}

Chemical compositions of representative samples of all described rock types are presented in Tables 1 and 2. Se- 
lected binary plots for the defined rock groups are given in Fig. 5.

Peraluminous granites of the Eisgarn suite are chemically comparable with the granites from the NE part of the South Bohemian pluton (Breiter - Koller 1999): the Žofín granite with the Číměr̆ granite and the Mandelstein granite with the Eisgarn s. s. granite (Fig. 6).

The Mandelstein granite is, in comparison with the Žofín granite, richer in $\mathrm{Na}, \mathrm{P}$, $\mathrm{F}, \mathrm{Rb}, \mathrm{U}, \mathrm{Nb}$ and $\mathrm{Sn}$ and poorer in $\mathrm{Mg}, \mathrm{Fe}$, $\mathrm{Ca}, \mathrm{K}, \mathrm{Zr}$, Sr, Th and REE. The Mandelstein body is internally zoned with a less fractionated rim and more fractionated core enriched in $\mathrm{Rb}, \mathrm{F}, \mathrm{Li}, \mathrm{Sn}$ and $\mathrm{Nb}$. This fractionation trend continues in the muscovite granites of Unterlembach and Pyhrabruck (Breiter - Scharbert 1998).

The group of biotite granites differs from the peraluminous two-mica granites generally in lower contents of $\mathrm{SiO}_{2}(65-72 \mathrm{wt}$ \% in biotite granites, 69-76 wt. \% in twomica granites). At the same $\mathrm{SiO}_{2}$, the biotite granites are slightly depleted in $\mathrm{K}$ and enriched in Ca compared to the two-mica granites. With increasing $\mathrm{SiO}_{2}$, the $\mathrm{Na}_{2} \mathrm{O}$ decreases and $\mathrm{K}_{2} \mathrm{O}$ increases (decrease of plagioclase, increase of $\mathrm{Kfs}$ ). The two-mica granites show opposite trends: Kfs decreases and albite increases.

Within the group of biotite granites, the Weitra (magnetic and non-magnetic facies) and the Karlstift granites differ significantly. The porphyritic facies of the Karlstift granite is the most $\mathrm{Si}$-poor, and $\mathrm{Ca}$-, $\mathrm{Sr}$ and $\mathrm{Zr}$-rich granite type in the area. The equigranular facies of Karlstift granite is chemically closer to the Weitra granite.

\section{$\mathrm{Rb}-\mathrm{Sr}$ isotopic results}

In the course of the years numerous Sr isotope data were accumulated on the different granite types in the Weitra - Nové Hrady area (Table 3), some of them published previously (Scharbert 1987; Breiter - Scharbert 1998; Humer et al. 2003). Twomica granites (Žofín and Mandelstein types) are characterised by $\mathrm{Rb}$ contents close to $300 \mathrm{ppm}$ and $\mathrm{Sr}$ values mostly lower than $100 \mathrm{ppm}$. In ${ }^{87} \mathrm{Sr} /{ }^{86} \mathrm{Sr}$ vs. ${ }^{87} \mathrm{Rb} /{ }^{86} \mathrm{Sr}$ diagrams (Fig. 7) the samples scatter considerably making precise age calculations impossible. According to the well established $\mathrm{Rb}-\mathrm{Sr}$ age of $314 \mathrm{Ma}$ of the Pyhrabruck-Nakolice intrusion, corroborated by $\mathrm{Ar}-\mathrm{Ar}$ cooling ages on muscovite
Table 1 Chemical composition of peraluminous two-mica granites. Major elements in wt. $\%$, trace elements in ppm. $Z=Z$ Zofín granite, $M=$ Mandelstein granite

\begin{tabular}{|c|c|c|c|c|c|c|c|c|c|}
\hline $\begin{array}{l}\text { Type } \\
\text { No. }\end{array}$ & $\begin{array}{c}Z \\
3125\end{array}$ & $\begin{array}{c}\mathrm{Z} \\
\mathbf{3 1 3 1}\end{array}$ & $\begin{array}{c}Z \\
3349\end{array}$ & $\begin{array}{c}Z \\
3320\end{array}$ & $\begin{array}{c}\text { M } \\
\mathbf{3 1 2 0}\end{array}$ & $\begin{array}{c}\text { M } \\
3121\end{array}$ & $\begin{array}{c}\text { M } \\
3122\end{array}$ & $\begin{array}{c}\text { M } \\
\mathbf{3 1 1 3}\end{array}$ & $\begin{array}{c}\text { M } \\
3115\end{array}$ \\
\hline $\mathrm{SiO}_{2}$ & 70.26 & 71.21 & 72.56 & 72.76 & 73.20 & 72.65 & 72.60 & 70.68 & 71.72 \\
\hline $\mathrm{TiO}_{2}^{2}$ & 0.48 & 0.29 & 0.34 & 0.28 & 0.12 & 0.26 & 0.22 & 0.35 & 0.30 \\
\hline $\mathrm{Al}_{2} \mathrm{O}_{3}$ & 14.43 & 14.91 & 14.06 & 14.21 & 14.89 & 14.16 & 14.45 & 15.17 & 14.82 \\
\hline $\mathrm{Fe}_{2} \mathrm{O}_{3}$ & 0.865 & 0.705 & 0.803 & 0.902 & 0.539 & 0.733 & 0.66 & 0.801 & 0.782 \\
\hline $\mathrm{FeO}$ & 1.75 & 0.85 & 0.96 & 0.52 & 0.55 & 1.05 & 0.99 & 1.34 & 1.24 \\
\hline MnO & 0.041 & 0.028 & 0.03 & 0.016 & 0.033 & 0.037 & 0.034 & 0.044 & 0.041 \\
\hline MgO & 0.86 & 0.45 & 0.45 & 0.28 & 0.19 & 0.33 & 0.32 & 0.47 & 0.41 \\
\hline $\mathrm{CaO}$ & 0.99 & 0.67 & 0.74 & 0.51 & 0.50 & 0.70 & 0.67 & 1.04 & 0.90 \\
\hline $\mathrm{Li}_{2} \mathrm{O}$ & 0.007 & 0.017 & 0.014 & 0.012 & 0.025 & 0.013 & 0.014 & 0.014 & 0.016 \\
\hline $\mathrm{Na}_{2} \mathrm{O}$ & 2.68 & 2.96 & 2.78 & 2.69 & 2.86 & 3.21 & 3.20 & 3.33 & 3.38 \\
\hline $\mathrm{K}_{2} \mathrm{O}$ & 5.13 & 5.45 & 5.53 & 5.58 & 5.42 & 4.74 & 5.00 & 4.98 & 4.96 \\
\hline $\mathrm{P}_{2} \mathrm{O}_{5}$ & 0.253 & 0.334 & 0.184 & 0.206 & 0.382 & 0.268 & 0.23 & 0.252 & 0.262 \\
\hline $\mathbf{F}^{2}$ & 0.132 & 0.155 & 0.121 & 0.08 & 0.174 & 0.091 & 0.079 & 0.10 & 0.113 \\
\hline L.O.I. & 1.28 & 1.22 & 1.11 & 1.25 & 1.14 & 1.08 & 1.09 & 1.21 & 1.09 \\
\hline Total & 99.10 & 99.18 & 99.63 & 99.26 & 99.95 & 99.28 & 99.53 & 99.74 & 99.99 \\
\hline A/CNK & 1.23 & 1.24 & 1.18 & 1.25 & 1.30 & 1.21 & 1.21 & 1.19 & 1.18 \\
\hline Sn & $<7$ & 12 & 6 & 9 & 12 & $<7$ & $<7$ & $<7$ & $<7$ \\
\hline Zn & 68 & 81 & 75 & 71 & 47 & 66 & 62 & 65 & 67 \\
\hline As & $<7$ & $<7$ & 6 & 7 & $<7$ & $<7$ & $<7$ & $<7$ & $<7$ \\
\hline $\mathrm{Nb}$ & 19 & 17 & 13 & 16 & 17 & 23 & 21 & 17 & 23 \\
\hline $\mathrm{Cu}$ & $<7$ & $<7$ & 8 & 4 & $<7$ & $<7$ & $<7$ & $<7$ & $<7$ \\
\hline $\mathbf{R b}$ & 260 & 343 & 322 & 331 & 450 & 314 & 308 & 280 & 303 \\
\hline $\mathbf{Z r}$ & 190 & 108 & 141 & 117 & 30 & 119 & 106 & 156 & 131 \\
\hline $\mathrm{Pb}$ & 12 & 16 & 29 & 29 & 12 & 13 & 17 & 21 & 13 \\
\hline $\mathrm{Sr}$ & 147 & 64 & 65 & 61 & 47 & 83 & 93 & 190 & 103 \\
\hline Th & 38 & 26 & n.a. & n.a. & 7.3 & 17 & 20 & 19 & 20 \\
\hline $\mathbf{U}$ & 6.3 & 7.2 & 11 & 11 & 7.5 & 7.8 & 7.3 & 7.9 & 6.7 \\
\hline $\mathbf{Y}$ & 22 & 10.8 & 15.3 & 8 & 15.5 & n.a. & n.a. & 22.1 & 21.3 \\
\hline La & n.a. & 30.6 & 45.8 & 31.6 & 11.4 & n.a. & n.a. & 37.5 & 36.5 \\
\hline $\mathrm{Ce}$ & n.a. & 66.2 & 98.7 & 75 & 24.5 & n.a. & n.a. & 79 & 76.1 \\
\hline $\operatorname{Pr}$ & n.a. & 8.3 & 12.3 & 7.6 & 3.3 & n.a. & n.a. & 10.3 & 9.3 \\
\hline Nd & n.a. & 33.7 & 44.1 & 34.3 & 10.6 & n.a. & n.a. & 36.5 & 33.8 \\
\hline Sm & n.a. & 7.52 & 10.29 & 8.57 & 3.26 & n.a. & n.a. & 7.32 & 6.93 \\
\hline $\mathbf{E u}$ & n.a. & 0.48 & 0.6 & 0.38 & 0.31 & n.a. & n.a. & 0.71 & 0.6 \\
\hline Gd & n.a. & 5.2 & 7.11 & 5.28 & 3.32 & n.a. & n.a. & 6.47 & 6.76 \\
\hline Tb & n.a. & $<0.7$ & 0.97 & $<0.7$ & $<0.7$ & n.a. & n.a. & 1.46 & 1.31 \\
\hline Dy & n.a. & 2.61 & 3.47 & 2.35 & 3.12 & n.a. & n.a. & 4.66 & 4.63 \\
\hline Ho & n.a. & 0.68 & 0.78 & 0.36 & 0.75 & n.a. & n.a. & 0.78 & 0.88 \\
\hline $\mathbf{E r}$ & n.a. & 0.99 & 1.33 & 0.57 & 1.13 & n.a. & n.a. & 1.55 & 1.89 \\
\hline Tm & n.a. & $<0.3$ & $<0.3$ & $<0.2$ & $<0.3$ & n.a. & n.a. & $<0.3$ & $<0.3$ \\
\hline $\mathbf{Y b}$ & n.a. & 0.65 & 1.10 & 0.43 & 1.13 & n.a. & n.a. & 1.70 & 1.54 \\
\hline Lu & n.a. & 0.09 & 0.16 & 0.06 & 0.15 & n.a. & n.a. & 0.24 & 0.21 \\
\hline
\end{tabular}

n.a. $=$ not analyzed

\section{Samples:}

3125 - large blocks E of the Schützenberg village on the eastern bank of river in the Lainsitz valey, $500 \mathrm{~m} \mathrm{~S}$ of the new motorway bridge, medium-grained slightly porphyritic biotite $>>$ muscovite granite,

3131 - blocks in a small forest $4 \mathrm{~km} \mathrm{SE}$ of Weitra, $2 \mathrm{~km} \mathrm{NE}$ of Spital, coarse-grained slightly porphyritic biotite $>$ muscovite granite,

3349 - Schwarzauer Hof, blocks $800 \mathrm{~m} \mathrm{NW}$ of the settlement, fine-grained slightly porphyritic biotite $>>$ muscovite granite,

3320 - Pohorská Ves, eastern slopes of the Červený Vrch hill, fine-grained two-mica granite,

3120 - Reinpolz, blocks NW of the village, coarse-grained slightly porphyritic two-mica granite,

3121 - Pyhrabruck, outcrop in a small valley SW of the village, medium-grained slightly porphyritic two-mica granite,

3122 - Forstberg, blocks in the forest $\mathrm{N}$ of Harbach, medium-grained slightly porphyritic biotite>muscovite granite,

3113 - Schagges, block in a small forest at the E margin of the village, medium-grained porphyritic biotite $>$ muscovite granite,

3115 - Heinrichs, $300 \mathrm{~m} \mathrm{~N}$ of the chapel "Gspeckte Buche", medium- to coarse-grained porphyritic two-mica granite. 
Table 2 Chemical composition of biotite and associated muscovite granites. Major elements in wt. \%, trace elements in ppm. $\mathrm{Wm}=$ magnetic facies of the Weitra granite, $\mathrm{Wn}=$ non-magnetic facies of the Weitra granite, $\mathrm{Mu}=$ muscovite granites associated with Weitra granite, $\mathrm{K}=$ Karlstift granite.

\begin{tabular}{|c|c|c|c|c|c|c|c|c|c|}
\hline $\begin{array}{l}\text { Type } \\
\text { No. }\end{array}$ & $\begin{array}{r}\text { Wm } \\
3225\end{array}$ & $\begin{array}{r}\text { Wm } \\
3422 \\
\end{array}$ & $\begin{array}{r}\text { Wm } \\
3223\end{array}$ & $\begin{array}{r}\text { Mu } \\
3393 \\
\end{array}$ & $\begin{array}{r}\text { Wn } \\
2493 \\
\end{array}$ & $\begin{array}{r}\text { Wn } \\
3347 \\
\end{array}$ & $\begin{array}{r}\text { Wn } \\
3348 \\
\end{array}$ & $\begin{array}{c}K \\
3355 \\
\end{array}$ & $\begin{array}{c}K \\
3395\end{array}$ \\
\hline $\mathrm{SiO}_{2}$ & 70.85 & 70.87 & 71.90 & 75.66 & 73.09 & 69.26 & 69.41 & 69.84 & 66.00 \\
\hline $\mathrm{TiO}_{2}$ & 0.44 & 0.50 & 0.41 & 0.08 & 0.41 & 0.50 & 0.53 & 0.52 & 0.67 \\
\hline $\mathrm{Al}_{2} \mathrm{O}_{3}$ & 14.36 & 14.16 & 13.92 & 13.65 & 13.24 & 14.69 & 14.66 & 14.67 & 15.10 \\
\hline $\mathrm{Fe}_{2} \mathrm{O}_{3}$ & 0.653 & 1.26 & 0.91 & 0.554 & 0.60 & 1.02 & 0.97 & 0.642 & 1.50 \\
\hline $\mathrm{FeO}$ & 1.50 & 1.63 & 1.08 & 0.14 & 1.65 & 1.65 & 1.71 & 1.78 & 2.15 \\
\hline MnO & 0.045 & 0.053 & 0.042 & 0.012 & 0.038 & 0.052 & 0.052 & 0.047 & 0.075 \\
\hline MgO & 0.69 & 0.80 & 0.67 & 0.09 & 0.73 & 0.82 & 0.86 & 0.80 & 1.30 \\
\hline $\mathrm{CaO}$ & 1.50 & 2.06 & 1.30 & 0.56 & 1.58 & 2.03 & 1.88 & 2.21 & 2.93 \\
\hline $\mathrm{Li}_{2} \mathrm{O}$ & 0.016 & 0.009 & 0.012 & 0.007 & 0.009 & 0.011 & 0.011 & 0.008 & 0.008 \\
\hline $\mathrm{Na}_{2} \mathrm{O}$ & 2.94 & 2.91 & 2.98 & 3.28 & 2.84 & 3.38 & 3.39 & 3.25 & 3.31 \\
\hline $\mathrm{K}_{2} \mathrm{O}$ & 4.90 & 5.01 & 4.77 & 4.36 & 4.34 & 4.51 & 4.49 & 4.26 & 3.83 \\
\hline $\mathrm{P}_{2} \mathrm{O}_{5}$ & 0.164 & 0.203 & 0.151 & 0.142 & 0.19 & 0.191 & 0.198 & 0.183 & 0.36 \\
\hline $\mathbf{F}$ & 0.122 & 0.128 & 0.091 & 0.058 & 0.136 & 0.137 & 0.099 & 0.098 & 0.125 \\
\hline L.O.I. & 1.02 & 0.83 & 1.00 & 0.94 & 0.87 & 0.96 & 1.04 & 0.99 & 1.06 \\
\hline Total & 99.15 & 100.47 & 99.2 & 99.52 & 99.76 & 99.25 & 99.37 & 99.26 & 98.37 \\
\hline A/CNK & 1.11 & 1.01 & 1.12 & 1.22 & 1.08 & 1.04 & 1.06 & 1.05 & 1.01 \\
\hline Sn & $<7$ & 3 & $<7$ & 42 & $<7$ & 3 & 5 & 2 & $<2$ \\
\hline $\mathrm{Zn}$ & 39 & 49 & 43 & 15 & 47 & 53 & 63 & 51 & 68 \\
\hline As & $<7$ & 6 & $<7$ & 6 & $<7$ & 6 & 6 & 6 & 7 \\
\hline $\mathbf{N b}$ & 15 & 16 & 15 & 19 & 13 & 14 & 15 & 12 & 19 \\
\hline $\mathrm{Cu}$ & $<7$ & 7 & $<7$ & 6 & 19 & 15 & 8 & 5 & 11 \\
\hline $\mathbf{R b}$ & 219 & 212 & 217 & 237 & 201 & 224 & 216 & 188 & 163 \\
\hline $\mathbf{Z r}$ & 157 & 187 & 148 & 8 & 162 & 194 & 195 & 191 & 280 \\
\hline $\mathbf{P b}$ & 19 & 29 & 19 & 27 & 29 & 24 & 28 & 35 & 35 \\
\hline $\mathrm{Sr}$ & 282 & 408 & 310 & 49 & 292 & 255 & 262 & 299 & 587 \\
\hline Th & 27.7 & n.a. & 26.1 & 4.5 & 23.7 & n.a. & n.a. & n.a. & 31.3 \\
\hline $\mathbf{U}$ & 8.6 & 8 & 7.3 & 5 & 8.3 & 4 & 5 & 4 & 4 \\
\hline $\mathbf{Y}$ & n.a. & 23.4 & n.a. & 10.6 & n.a. & 21.9 & 21.6 & 21.9 & 32.6 \\
\hline La & n.a. & 51.6 & n.a. & 4.8 & n.a. & 42.6 & 37.9 & 42.4 & 80.6 \\
\hline $\mathrm{Ce}$ & n.a. & 111.2 & n.a. & 6.7 & n.a. & 84.0 & 84.7 & 89.6 & 173.8 \\
\hline Pr & n.a. & 11.9 & n.a. & 1.0 & n.a. & 9.6 & 10.6 & 9.5 & 17.3 \\
\hline Nd & n.a. & 48.9 & n.a. & 3.3 & n.a. & 37.0 & 38.3 & 39.9 & 71.9 \\
\hline Sm & n.a. & 10.24 & n.a. & 1.01 & n.a. & 8.58 & 7.11 & 8.75 & 13.54 \\
\hline $\mathbf{E u}$ & n.a. & 1.04 & n.a. & 0.23 & n.a. & 0.92 & 0.92 & 1.01 & 1.85 \\
\hline Gd & n.a. & 6.62 & n.a. & 0.92 & n.a. & 6.07 & 6.24 & 5.84 & 9.36 \\
\hline $\mathbf{T b}$ & n.a. & 1.49 & n.a. & $<0.7$ & n.a. & 1.41 & 1.49 & 0.86 & 1.48 \\
\hline Dy & n.a. & 5.0 & n.a. & 1.7 & n.a. & 4.12 & 4.31 & 4.49 & 6.64 \\
\hline Но & n.a. & 1.17 & n.a. & $<0.5$ & n.a. & $<0.5$ & 1.22 & 1.40 & 1.52 \\
\hline $\mathbf{E r}$ & n.a. & 2.40 & n.a. & 1.10 & n.a. & 1.72 & 1.82 & 2.80 & 3.12 \\
\hline Tm & n.a. & 0.37 & n.a. & $<0.3$ & n.a. & $<0.3$ & 0.38 & 0.44 & 0.62 \\
\hline $\mathbf{Y b}$ & n.a. & 2.15 & n.a. & 1.7 & n.a. & 2.03 & 2.0 & 2.06 & 3.16 \\
\hline Lu & n.a. & 0.32 & n.a. & 0.26 & n.a. & 0.30 & 0.29 & 0.29 & 0.46 \\
\hline
\end{tabular}

\section{Samples:}

3225 - Steinerne Frau, $1 \mathrm{~km}$ WSW of Wultschau, medium-grained porphyritic biotite granite,

3422 - drilling MOK-1 near St. Martin, depth 253.6-254.0 m, medium-grained porphyritic biotite granite,

3223 - St. Martin, $1 \mathrm{~km}$ E of the village, southern slopes of the Mitterbühel hill, medium-grained porphyritic biotite granite,

3393 - St. Martin, $1 \mathrm{~km} \mathrm{NE}$ of the village, summit of the Mitterbühel hill, mediumgrained muscovite granite,

2493 - Weitra, road cut in the western part of the town at the road to Wultschau, medium-grained biotite granite with some muscovite,

3347 - Harmanschlag, $1 \mathrm{~km} \mathrm{~N}$ of the village, SE slope of the Gemeindeberg hill, finegrained porphyritic biotite granite,

3348 - between Nebelstein and Althütten, fine-grained porphyritic biotite granite,

3355 - at the road Karlstift - Langschlag, $3 \mathrm{~km}$ E of Karlstift, medium-grained porphyritic biotite granite, central facies of the "Karlstift" body,

3395 - at the road Karlstift - Langschlag, $2 \mathrm{~km}$ to the W of Siebenhof, medium-grained porphyritic biotite granite, pericontact facies of the Karlstift type.
(314-312 Ma), the emplacement of the surrounding Mandelstein intrusion took place (slightly) earlier than 314 Ma. An errorchron for the Žofín granite yielded an age of $324 \pm 14 \mathrm{Ma}$.

Biotite granites not only have different texture and modal composition, but differ significantly in having lower $\mathrm{Rb}$ and (three- to fourfold) higher Sr-contents. Humer et al. (2003) compared those with the Mauthausen type granite because of similar geochemical composition and calculated therefore initial $\mathrm{Sr}$ ratios for the time of $315 \mathrm{Ma}$. We followed their procedure for all granite varieties and calculated initial $\mathrm{Sr}$ isotopic ratios for $315 \mathrm{Ma}$ (Table 3). Biotite granites of the Weitra type yield uniform values of 0.705 , the sample from the Nebelstein suite drill hole NEK 7 lying slightly above. The Karlstift biotite granite (both porphyritic and equigranular facies) has ${ }^{87} \mathrm{Sr} /{ }^{86} \mathrm{Sr}_{315}=0.7065-0.7067$. As expected, initial $\mathrm{Sr}$ isotopic ratios for the two-mica Žofín-type granite from the E, S and $\mathrm{W}$ surroundings of Weitra and from the body extending NW of Nové Hrady are higher and scatter around 0.713 . The samples from the Mandelstein body ( $\mathrm{N}$ and NW of Weitra) have low initial $\mathrm{Sr}$ isotopic ratios (0.705-0.707: Table 3).

\section{Discussion}

\section{Two-mica granites}

Field mapping and whole-rock and mineral chemical analyses suggested zoned structure of the two-mica granite intrusions between Weitra and Nové Hrady, with higher degree of magmatic fractionation towards the centre near Pyhrabruck. This led Breiter - Scharbert (2001) to define two local granite facies - the less evolved, finegrained "Aussengranite" at the rim, and the more fractionated, coarse-grained "Eisgarn s. s." in the centre. Both of them, together with the muscovite Nakolice-Pyhrabruck granite, were supposed to be products of fractionation from the same parental peraluminous Eisgarn-like melt. On the basis of the new Sr isotope data is concluded that there in fact exist two intrusions of different genetic origin. Therefore we introduced for both granite types new local names Žofín and Mandelstein.

The Žofín granite forms external parts occupied by two-mica granites (formerly Aussengranite) and is comparable well 

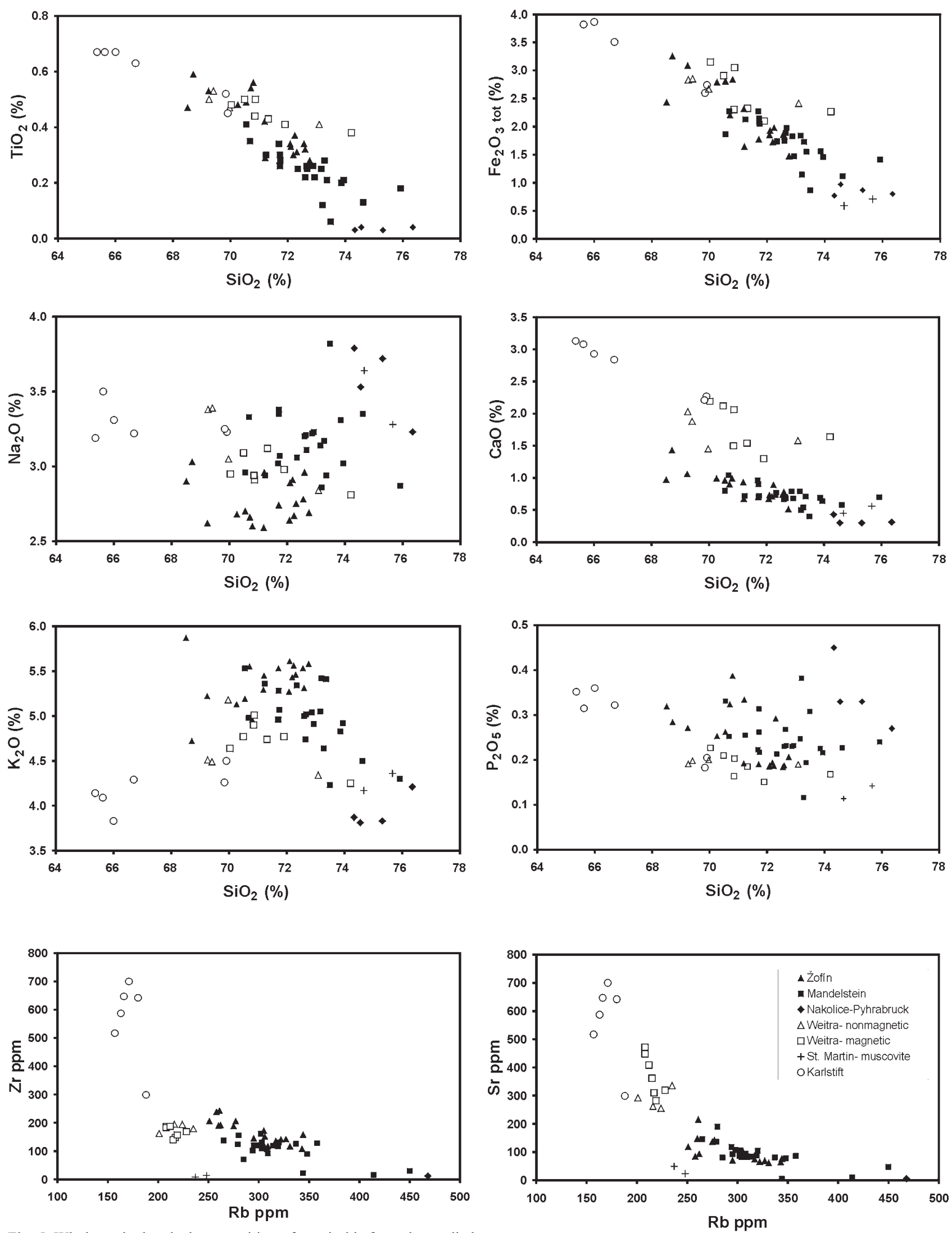

Fig. 5 Whole-rock chemical composition of granitoids from the studied area. 
with other intrusions of the Eisgarn suite throughout the whole Moldanubicum (Scharbert 1998). Its initial Sr isotopic ratios $\sim 0.713$ indicate a predominantly metasedimentary source. The Mandelstein granite is also peraluminous, but slightly richer in $\mathrm{Na}_{2} \mathrm{O}$ and poorer in $\mathrm{K}_{2} \mathrm{O}$, with conspicouously lower contents of $\mathrm{Zr}$ and $\mathrm{Ce}$ and slightly higher $\mathrm{Rb}$ and $\mathrm{Sr}$. Zoned structure with enrichment of $\mathrm{Na}, \mathrm{Rb}, \mathrm{F}$ and $\mathrm{U}$ towards the centre is well documented, being comparable to the internal zoning of the Eisgarn (s. s.) body N of Gmünd (Breiter - Koller 1999). Distinctly lower Sr initial isotope ratios of the Mandelstein granite (are c. 0.706-0.707) exclude its classification as a member of Eisgarn suite. Associated muscovite granites such as Nakolice-Pyhrabruck (Breiter - Scharbert 1998 ) yield also similarly low ${ }^{87} \mathrm{Sr} /{ }^{86} \mathrm{Sr}_{i}$ of 0.707 and seem to be the final products of the Mandelstein-like melt fractionation. Low initial $\mathrm{Sr}$ isotope ratios of Mandelstein
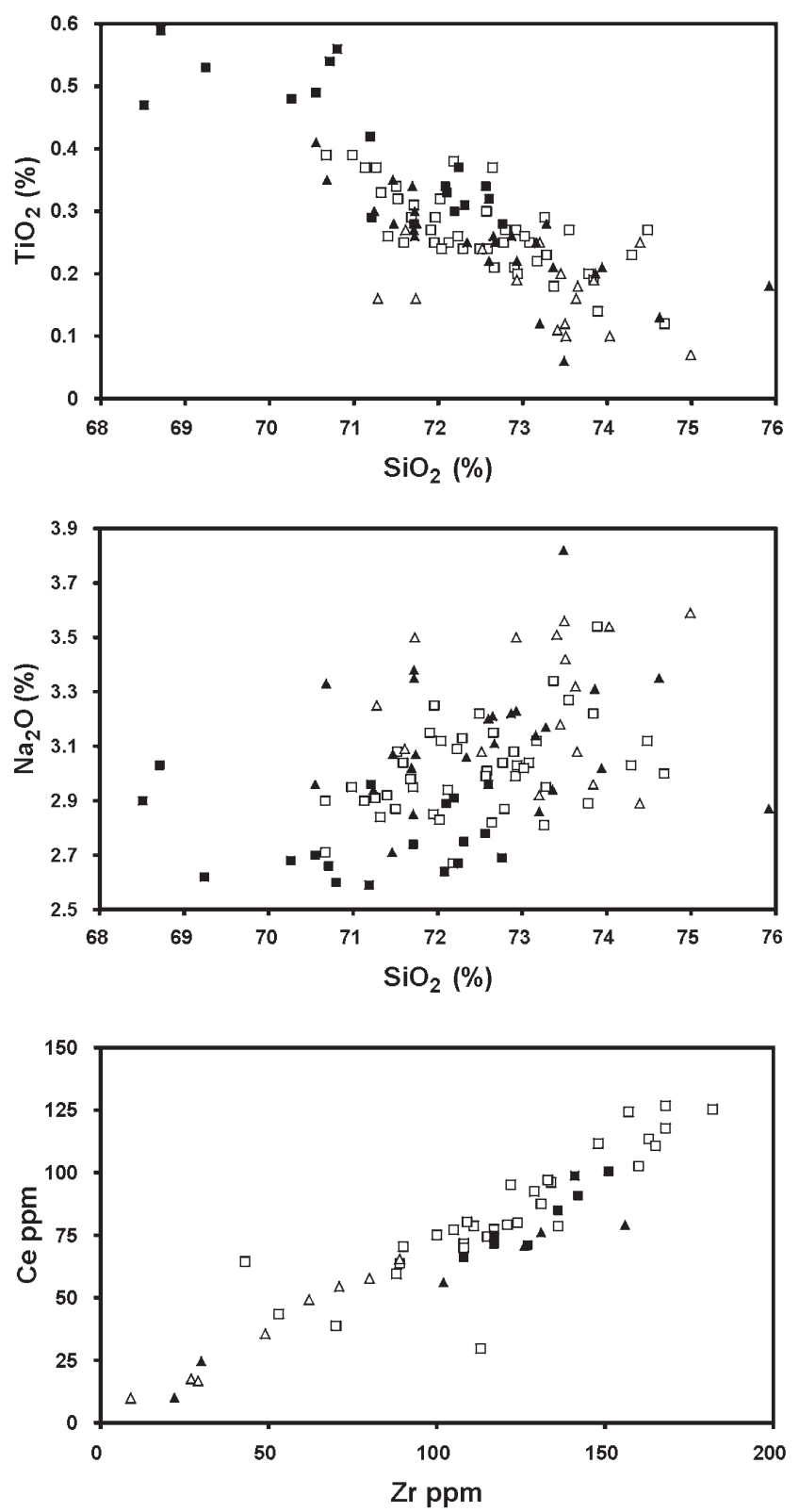

- Pyhrabruck suite may indicate changes in the magma sources at the end of Variscan magmatic cycle. These changes are distinct not only between the peraluminous Eisgarn s.1. and metaaluminous (Mauthausen-Freistadt) suites (Gerdes 1997, Janoušek et al. 2002), but also in the peraluminous suite itself.

Relative age of the Weinsberg biotite granite and individual types of peraluminous granites is geologically well established; the granites intruded in order Weinsberg granite $\rightarrow$ Žofín granite $\rightarrow$ Mandelstein granite $\rightarrow$ muscovite granites of Unterlembach, Oberlembach and Nakolice-Pyhrabruck bodies. The biotite granites of the Weitra pluton and Karlstift granite are geologically younger than the Weinsberg granite but their geological relation to the two-mica granites is not clear.

The age of individual two-mica granite intrusions can be constrained only indirectly. All two-mica granites are
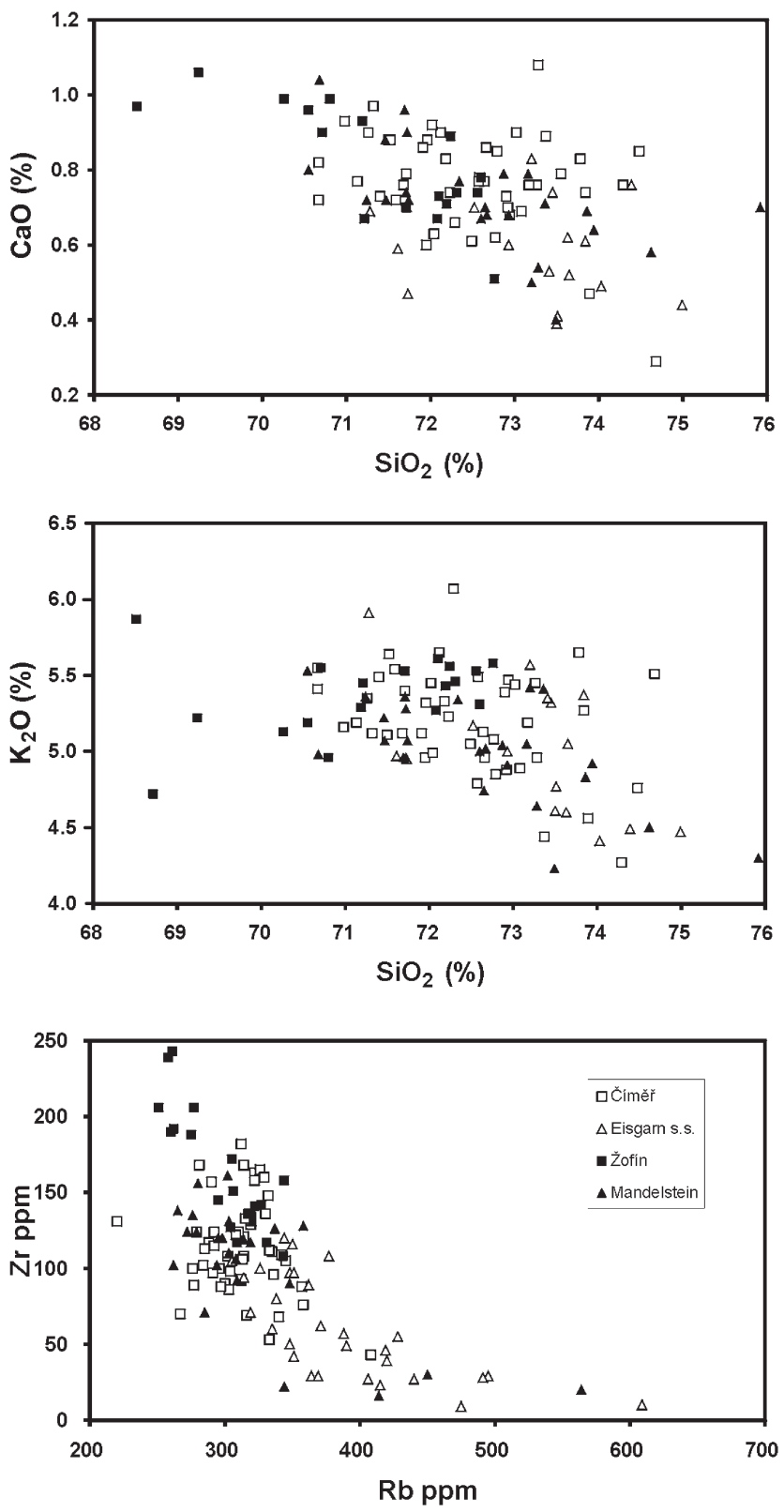

Fig. 6 Comparison of the studied two-mica granites with granitoid rocks from the NE part of the South Bohemian Pluton. 
Ta ble 3 Isotope data for granites from the Weitra - Nové Hrady area. Samples from Nakolice-Pyhrabruck are from Breiter - Scharbert (1998). For comparison, also one sample of Mandelstein granite analysed by Gerdes (1997) is presented.

\begin{tabular}{|c|c|c|c|c|c|c|c|c|c|}
\hline sample & locality & $\begin{array}{r}\text { Rb } \\
\text { ppm }\end{array}$ & $\begin{array}{r}\mathrm{Sr} \\
\mathrm{ppm}\end{array}$ & $\begin{array}{c}{ }^{87} \mathrm{Rb} / \\
{ }^{86} \mathrm{Sr}\end{array}$ & $\begin{array}{l}{ }^{87} \mathrm{Sr} / \\
{ }^{86} \mathrm{Sr}\end{array}$ & 2 sigma & $\begin{array}{c}{ }^{87} \mathrm{Sr} /{ }^{86} \mathrm{Sr} \\
315 \mathrm{Ma}\end{array}$ & $\begin{array}{r}\text { Ar-Ar } \\
\mathbf{M u}\end{array}$ & $\begin{array}{r}\text { Ar-Ar } \\
\text { Bt }\end{array}$ \\
\hline \multicolumn{10}{|l|}{ Two-mica granites } \\
\hline \multicolumn{10}{|l|}{ Nakolice-Pyhrabruck } \\
\hline $44 / 94$ & Pyhrabruck & 814 & 14.9 & 169 & 1.46277 & 0.00011 & 0.705 & $312 \pm 2$ & \\
\hline $45 / 94$ & Pyhrabruck & 634 & 22.8 & 83.5 & 1.07942 & 0.00017 & 0.705 & & \\
\hline $46 / 94$ & Pyhrabruck & 709 & 15.1 & 144 & 1.34812 & 0.00006 & 0.702 & & \\
\hline $47 / 94$ & Pyhrabruck & 818 & 14.5 & 176 & 1.49351 & 0.00023 & 0.704 & & \\
\hline $48 / 94$ & Pyhrabruck & 797 & 24.8 & 96.8 & 1.14238 & 0.00011 & 0.708 & & \\
\hline $49 / 94$ & Pyhrabruck & 714 & 7.94 & 294 & 2.02834 & 0.00027 & 0.710 & $313 \pm 2$ & \\
\hline $50 / 94$ & Pyhrabruck & 813 & 13.9 & 182 & 1.51038 & 0.00019 & 0.694 & & \\
\hline $51 / 94$ & Pyhrabruck & & & & & & & $312 \pm 2$ & \\
\hline $52 / 94$ & Pyhrabruck & 721 & 17.5 & 126 & 1.27514 & 0.00013 & 0.710 & $314 \pm 2$ & \\
\hline \multicolumn{10}{|l|}{ Mandelstein granite } \\
\hline $31 / 96=3193$ & E Schagges & 297 & 112.0 & 7.72 & 0.74123 & 0.00017 & 0.7066 & $304 \pm 3$ & $291 \pm 2$ \\
\hline $17 / 97$ & Mandelstein & 329 & 81.9 & 11.70 & 0.75678 & 0.00008 & 0.7043 & $312 \pm 3$ & \\
\hline $18 / 97$ & Mandelstein & 333 & 94.2 & 10.30 & 0.75250 & 0.00006 & 0.7063 & $312 \pm 2$ & \\
\hline $19 / 97$ & S Pyhrabruck & 339 & 86.1 & 11.50 & 0.75698 & 0.00005 & 0.7054 & $307 \pm 2$ & \\
\hline $20 / 97$ & S Pyhrabruck & 306 & 90.4 & 9.84 & 0.75144 & 0.00007 & 0.7073 & $307 \pm 2$ & \\
\hline $13 / 96$ & SO Nakolice & 343 & 70.5 & 14.17 & 0.76997 & 0.00010 & 0.7064 & $314 \pm 2$ & 332 excess Ar \\
\hline Eg 30/54 (Gerdes 1997) & 10 km NW Weitra & 346 & 75.7 & 13.31 & 0.76704 & & 0.70832 & & \\
\hline \multicolumn{10}{|c|}{ Žofin granite } \\
\hline $1 / 95$ & Altweitra & 266 & 130.0 & 5.97 & 0.74022 & 0.00007 & 0.7134 & $303 \pm 2$ & \\
\hline $8 / 96$ & Žofín & 324 & 72.4 & 13.03 & 0.77288 & 0.00018 & 0.7144 & $313 \pm 2$ & $307 \pm 2$ \\
\hline $9 / 96$ & Žofín & 335 & 71.0 & 13.75 & 0.7765 & 0.00011 & 0.7148 & & \\
\hline $11 / 96$ & Žd’ár & 276 & 76.3 & 10.51 & 0.76043 & 0.00011 & 0.7133 & $313 \pm 2$ & \\
\hline $12 / 96$ & N. Hrady-Bravery & 307 & 67.7 & 13.20 & 0.77370 & 0.00009 & 0.7145 & $307 \pm 3$ & 316 excess Ar \\
\hline $28 / 99=3222$ & SO Weitra & 305 & 68.0 & 13.00 & 0.77197 & 0.00007 & 0.7136 & & \\
\hline $31 / 99=3226$ & E Weitra & 282 & 92.5 & 8.87 & 0.75254 & 0.00006 & 0.7127 & & \\
\hline $19 / 00=3321$ & E Lužnice & 342 & 67.7 & 14.70 & 0.7792 & 0.0004 & 0.7132 & & \\
\hline $22 / 00$ & Kohout & 221 & 108.0 & 5.91 & 0.7367 & 0.0003 & 0.7102 & & \\
\hline \multicolumn{10}{|l|}{ Biotite granites } \\
\hline \multicolumn{10}{|l|}{ Weitra granite } \\
\hline $28 / 96=3192$ & Weitra & 244 & 323 & 2.19 & 0.71535 & 0.00005 & 0.7055 & $305 \pm 2$ & $284 \pm 2$ \\
\hline 29/99 & E Martin & 238 & 318 & 2.18 & 0.71503 & 0.00007 & 0.7053 & & \\
\hline $30 / 99=3225$ & St. Frau & 242 & 284 & 2.47 & 0.71668 & 0.00005 & 0.7056 & & \\
\hline $1 / 96$ & MOK-1 St. Martin & 201 & 465 & 1.25 & 0.71040 & 0.00004 & 0.7048 & $311 \pm 3$ & \\
\hline $2 / 96$ & MOK-2 St. Martin & 232 & 478 & 1.40 & 0.71106 & 0.00013 & 0.7048 & & \\
\hline \multicolumn{10}{|l|}{ Nebelstein } \\
\hline 43/85 (NEK 7) & Nebelstein & 222 & 278 & 2318 & 0.71688 & 0.00008 & 0.7064 & & \\
\hline \multicolumn{10}{|l|}{ Karlstift granite } \\
\hline $35 / 87$ & NW Liebenau & 157 & 517 & 0.882 & 0.71053 & 0.00003 & 0.7065 & & \\
\hline $36 / 87$ & NW Liebenau & 180 & 624 & 0.836 & 0.71031 & 0.00005 & 0.7065 & & \\
\hline $37 / 87$ & NW Liebenau & 180 & 647 & 0.807 & 0.71022 & 0.00007 & 0.7066 & & \\
\hline $4 / 88$ & NE Liebenau & 172 & 712 & 0.701 & 0.70978 & 0.00005 & 0.7066 & & \\
\hline $5 / 88$ & NE Liebenau & 171 & 702 & 0.707 & 0.70992 & 0.00007 & 0.7067 & & \\
\hline $7 / 88$ & NE Liebenau & 179 & 671 & 0.776 & 0.71003 & 0.00008 & 0.7065 & & \\
\hline
\end{tabular}

younger than the Weinsberg granite, dated at 323-331 Ma (conventional single-grain U-Pb zircon age, Gerdes et al. 2003). The lower age constraint is provided by Ar-Ar muscovite ages from muscovite granites (314-312 $\pm 2 \mathrm{Ma}$ in Nakolice-Pyhrabruck intrusion). From northeast to southwest the Ar-Ar ages decrease. Eisgarn s. s. granite $\mathrm{N}$ of Gmünd and its fractionated muscovite counterparts (Homolka and Galthof) are $320 \pm 2 \mathrm{Ma}$ and $315 \pm 3 \mathrm{Ma}$ 


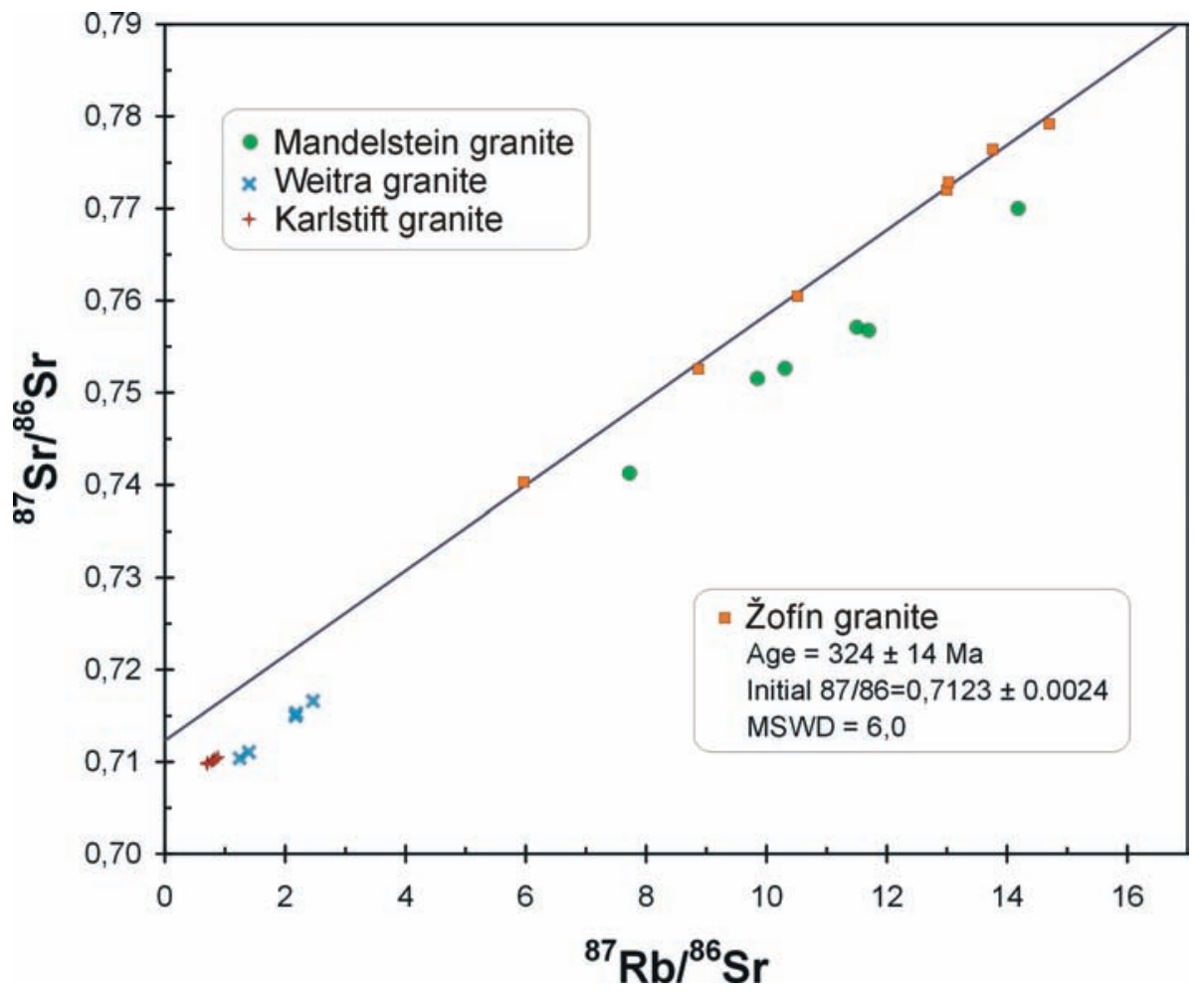

Fig. $7 \mathrm{Rb}-\mathrm{Sr}$ evolution diagram of two-mica and biotite granites of the Weitra - Nové Hrady area. old, respectively, both having high initial $\mathrm{Sr}$ isotope ratios (Scharbert et al. 1997, Breiter - Scharbert 1995, 1998). The Mandelstein granite is intruded by the PyhrabruckNakolice muscovite granite; so the former must be older than 312 Ma. Both Mandelstein and Pyhrabruck-Nakolice granites have low $\mathrm{Sr}$ initial isotope ratios. The $\mathrm{Rb}-\mathrm{Sr}$ isotope data for the Žofín granite give very inaccurate age. However, in respect to its initial $\mathrm{Sr}$ isotope composition, the Žofín granite is closest to the Eisgarn s. s. granite from the area $\mathrm{N}$ of Gmünd. Nebelstein granite shows a $\mathrm{Rb}-\mathrm{Sr}$ whole-rock age of $311.6 \pm 1.4 \mathrm{Ma}$ (Scharbert 1987), well comparable with Ar-Ar muscovite age of 312-308 Ma (Dallmeyer et al. 1995). The Nebelstein granite is closely associated with the Weitra intrusion (Humer et al. 2003), the latter being accordingly older, but both with similarly low $\mathrm{Sr}$ initial isotope ratios.

New chemical data from the "Eisgarn granite from the Weitra area" published by Humer - Finger (2002) and Humer et al. (2003) are concordant with our data for the Žofín granite, but not with those from the Mandelstein granite. This means that Humer et al. (1. c.) in fact characterised samples corresponding to the presently defined Žofín granite from the Weitra neighbourhood, not samples from the Mandelstein granite.

\section{Karlstift granite}

The term "granite of Karlstift" introduced by Klob (1970) for distinctly porphyritic biotite granites in the Karlstift area was later accepted also by Gnojek - Přichystal (1997). However, the areal extent of the Karlstift granite mapped by Gnojek - Přichystal is much smaller than that published by Klob (1. c.). In the geological map
ÖK18 (Fuchs - Schweighofer 1977) this granite (here named "porphyritic fine-grained granite") has even a smaller extent than in the maps by Gnojek - Prichystal. In our view the map by Gnojek - Prrichystal (1. c.) is the most realistic. The porphyritic granite forms the $\mathrm{N}$ and NE pericontact part of a much larger intrusion of equigranular biotite granite, termed "Mauthausen type" by both Fuchs - Schweighofer as well as Gnojek and Přichystal. Nevertheless, the term "Mauthausen granite" was used by numerous authors as a synonym for all medium-to fine grained granites in the Mühlviertel and Waldviertel, often also for those belonging undoubtedly to the Eisgan s. 1. suite. For instance, this was the case for the body SW of Harbach on the map sheet Weitra (Fuchs - Schweighofer 1977) or the body E of Eisgarn on the map sheet Gmünd (Waldmann 1950). Thus, the name Mauthausen bears great confusion in granite typology and should be either carefully revised, or rejected, best restricted to the type locality.

The contact between the outer porphyritic Karlstift granite and the inner equigranular biotite granite is not exposed. According to the sharp gradient in magnetic field data and contrasting chemistry of analysed samples along the expected contact, the latter should be either abrupt or transitional over a distance of a few metres. The porphyritic granite may be a slightly older magmatic pulse, preceding the major intrusion of the equigranular granite. Compared with the Weitra granite, the central equigranular variety of the Karlstift granite is chemically similar, but the porphyritic variety of the Karlstift granite is distinctly more basic, richer in $\mathrm{Ca}$ and has $\mathrm{Rb}$ and Sr contents significantly different from all other biotite granites. 


\section{The Weitra granite}

Gnojek - Přichystal (1997) found in the southern surroundings of Weitra two types of biotite granites differing in magnetic susceptibility. In absence of chemical data from these new granite varieties, they employed a classification on the basis of magnetic properties and radioactivity only: the magnetic biotite granite as a Karlstift granite, the non-magnetic biotite granite as a Mauthausen granite. Later, Humer et al. (2003) combined both magnetic and non-magnetic granites into a newly defined "Weitra pluton" with substantially larger extent than was the combined area of both types defined by Gnojek - Přichystal (1997).

The magnetic and the non-magnetic varieties of biotite granite from Weitra, St. Martin and Althüten are chemically identical. Crystallisation of magnetite can be explained as a result of local post-magmatic alteration (M. Chlupáčová, pers. comm.). According to our field experience, the areal extent of this granite is smaller than defined by Humer et al. (2003) under term of "Weitra granite". These authors defined three subtypes of the Weitra granite: the main type, the western type and the type of Schützenberg. The "western subtype" of Humer et al. corresponds well to our body of non-magnetic variety of Weitra granite near Althüten. The "main type" of Humer et al. builds two larger bodies. The intrsuion NE of St. Martin corresponds well with Gnojek - Přichystal's (1997) and our magnetic variety of the Weitra (sensu Humer et al. 2003) granite. The body inside the town of Weitra belongs to the Weitra non-magnetic granite.

The area of Schützenberg type stretching SW of Weitra is, with the exception of the Lainsitz valley, poorly exposed. Humer et al. (1. c.) themselves mentioned its peraluminous character and higher $\mathrm{P}, \mathrm{Rb}$ and $\mathrm{Zr}$ contents and lower REE contents in comparison with the "main type of Weitra granite". Our data from the outcrops in Lainsitz valley correspond more to the Žofín granite. But on the other side, initial $\mathrm{Sr}$ isotopic ratio $\sim 0.707$ published by Humer et al. (2003) in sample from the village of Schützenberg may mean, that this area is more complicated and the peraluminous Žofín granite alternate here with small apophyses of the Weitra-type biotite granite.

To the NE of St. Martin, the Weitra granite is accompanied by small bodies of muscovite granites. As discussed in detail by Humer et al. (2003), the larger complex of the more fractionated two-mica to muscovite granites at Nebelstein (Göd - Koller 1989) should be also attributed to the evolution line of the Weitra granite given their whole-rock geochemical signature and low $\mathrm{Sr}$ initial isotopic ratios $(\sim 0.7055$ : Scharbert 1987).

The Weitra-type biotite granites at Weitra, St. Martin and Althüten differ significantly from the porphyritic Karlstift biotite granite in trace-element contents and Srisotopic compositions, indicating that these two rock types could be hardly cogenetic (see also Humer et al. 2003).

\section{Conclusions}

In the investigated area between Weitra and Nové Hrady - apart from the Weinsberg suite - four geochemically distinguishable intrusive units were defined:

Peraluminous Žofín granite, which forms outer part of the composite body of two-mica granites between Weitra and Nové Hrady. It is fine-grained, slightly porphyritic biotite-muscovite granite, texturally and chemically comparable with the Mrákotín and Č́měř granites from the northern part of the South Bohemian Pluton. Isotopically, it resembles typical Eisgarn granite with ${ }^{87} \mathrm{Sr} /{ }^{86} \mathrm{Sr}_{\mathrm{i}}$ $\sim 0.713$.

Peraluminous, fractionated suite of two-mica Mandelstein as well as muscovite Nakolice-Pyhrabruck and Šejby granites form inner part of the composite body between Weitra and Nové Hrady. This coarse-grained two-mica Mandelstein granite is texturally and chemically similar to the Eisgarn s.s. body $\mathrm{N}$ of Gmünd. Like the Eisgarn s. s. intrusion, it is also internally zoned with distinctly more fractionated core than rim. The Mandelstein granite differs from Eisgarn s. s. granite and the whole Eisgarn suite by much lower ${ }^{87} \mathrm{Sr}^{86} \mathrm{Sr}_{\mathrm{i}}$ $\sim 0.706-0.707$.

Porphyritic Karlstift biotite granite (sensu Klob 1970) has high magnetic susceptibility and shows only a very small degree of fractionation. Typical are the very high contents of $\mathrm{Sr} \sim 600 \mathrm{ppm}$. The initial $\mathrm{Sr}$ isotopic ratios are close to 0.706 .

Weitra biotite granite with magnetic and non-magnetic varieties, followed by dykes and stocks of muscovite granite. The ${ }^{87} \mathrm{Sr} /{ }^{86} \mathrm{Sr}_{\mathrm{i}}$ of 0.705 are the lowest of all the studied rocks. The areal extent of the Weitra granite seems smaller than that proposed originally by Humer et al. (2003).

The relative ages of the Weinsberg biotite granite and individual types of peraluminous granites are well established: Weinsberg granite $\rightarrow$ Žofín granite $\rightarrow$ Mandelstein granite $\rightarrow$ muscovite granites of Unterlembach, Oberlembach and Nakolice-Pyhrabruck bodies. The biotite granites of the Weitra and Karlstift intrusions are relatively younger than the Weinsberg granite. The geological relation to the two-mica granites is impossible to deduce. The probable ages of the discussed granites (excl. Karlstift granite) fall between 331-323 Ma (U-Pb age of Weinsberg granite, Gerdes et al. 2003) and c. $310 \mathrm{Ma}$ (Ar-Ar ages of muscovite from the youngest muscovite granites intruding the two-mica granites and the Weitra granite).

Acknowledgements. This work was undertaken in the framework of bilateral cooperation between the Geologische Bundesanstalt Wien and the Czech Geological Survey Praha and by the Austrian-Czech agency AKTION, project 2001-2. We thank Mrs. M. Jelenc, Dr. R. Schuster and Prof. W. Frank for support in geochronological isotopic analyses. An anonymous reviewer, B. Humer and S. Vrána are thanked for reviews. Revision of the English by V. Janoušek is acknowledged.

Submitted January 29, 2006 


\section{References}

Breiter, K. - Koller, F. (1999): Two-mica granites in the central part of the South Bohemian Pluton. - Abh. Geol. B.-A., 56: 201-212.

Breiter, K. - Scharbert, S. (1995): The Homolka Magmatic Centre - an Example of Late Variscan Ore Bearing Magmatism in the Southbohemian Batholith. - Jb. Geol. B.-A., 138: 9-25.

- (1998): Latest intrusions of the Eisgarn pluton (South Bohemia Northern Waldviertel). - Jb. Geol. B.-A., 141: 25-37. Wien.

- (2001): Geological mapping of the two-mica granites in the WeitraNové Hrady area. - Mitt. Österr. mineral. Ges., 146: 40-41.

Dallmeyer, R. D. - Fallick, A. E. - Koller, F. - Slapansky, P. (1995): The Nebelstein complex: a Variscan mineralized granite intrusion in the Bohemian Massif (Austria). - Eur. Jour. Mineral., 7, Beiheft 1: 52.

Erich, A. - Schwaighofer, B. (1977): Geologische Karte der Republik Österreich 1:50000, Blatt 18 Weitra. - Geol. B.-A., Wien

Finger, F. - Friedl, G. (2002): Der südböhmische Batholith: Granitoide der Sauwald- und Mühlzone. Exkursionsführer PANGEO Austria 2002. - 17 p. Salzburg.

Franke, W. - Haak, V. - Oncken, O. - Tanner, D. (2000): Orogenic processes: Quantification and modelling in the Variscan belt. - Geol. Soc. Spec. Publ. 179, 459 p., Geological Society London.

Fuchs, G. - Schwaighofer, B. (1978): Geologische Karte der Republik Österreich 1:50000, Blatt 17 Grosspertholz. Geol. B.-A. Wien

Fuchs, G. - Thiele, O. (1968): Erläuterungen zur Übersichtskarte des kristallins im westlichen Mühlviertel und im Sauwald, Oberösterreich. 96 p. Geol. B.-A. Wien.

Gerdes, A. (1997): Geochemische und thermische Modelle zur Frage der spätorogenen Granitgenese am Beispiel des Südböhmischen Batholiths: Basaltisches Underplating oder Krustenstapelung? Dissertation Universitaet Göttingen. 113 pp.

Gerdes, A. - Friedl, G. - Parrish, R. R. - Finger, F. (2003): High resolution geochronology of Variscan granite emplacement - the South Bohemian Batholith. - J. Czech. Geol. Soc., 48: 53-54.

Gnojek, I. - Prrichystal, A. (1997): Ground geophysical and geological mapping in the central part of the Moldanubian Pluton. - Jb. Geol. B.-A., 140: 193-250. Wien.

$G o ̈ d, R$. (1989): A contribution to the mineral potential of the southern Bohemian massif. -Arch. f. Lagerst. Forsch. Geol. B.-A., 11: 147153. Wien.
Göd, R. - Koller, F. (1989): Molybdän-führende Greisen im nördlichen Waldviertel. - Mitt. Österr. miner. Ges., 134: 114.

Heinz, H. - Seiberl, W. (1990): Bewertung und Problematik aerogeophysikalischer Anomalien im österreichischen Bundesgebiet (Stand: Mitte 1990). - Abh. Geol. Bundesanstalt, B. 44: 1-244. Wien.

Humer, B. - Finger, F. (2002): Der Eisgarner Granit im Raum Weitra, Niederösterreich. -PANGEO Austria, Programm et Kurzfassungen, p. 84 , Salzburg.

Humer, B. - Gerdes, A. - Finger, F. (2003): Der Weitraer Granit im nordwestlichen Niederösterreich - eine späte hochplutonische I-Typ Granitintrusion mit Greisenbildung im variszischen Südböhmischen Batholith. - Zbl. Geol. Paläontol. Teil. I, 2002, 213-235.

Janoušek, V. - Vrána, S. - Erban, V. (2002): Petrology, geochemical character and petrogenesis of a Variscan post-orogenic granite: case study from the Ševětín Massif, Moldanubian Batholith, Southern Bohemia. J. Czech geol. Soc., 47: 1-22.

Klob, H. (1970): Über das Vorkommen eines porphyrischen Granites im Raume Sandl-Karlstift-Liebenau bei Freistadt im oberösterreichischen Mühlviertel (Granit von Typ "Karlstift”). - Tschermaks Miner. Petrogr. Mitt., 14: 311-323.

Koller, F. - Klötzli, U. (1998): The evolution of the South Bohemian Pluton. - In: Breiter, K. (ed): Genetic significance of phosphorus in fractionated granites. Excursion guide, 11-14, C̆GÚ Praha.

Scharbert, S. (1987): Rb-Sr Untersuchungen granitoider Gesteine des Moldanubikums in Österreich. - Mitt. Österr. mineral. Ges., 132: 21-37.

- (1998): Some geochronological data from the South Bohemian Pluton in Austria: a critical review. - Acta Univ. Carol., Geol. 42: 114118.

Scharbert, S. - Breiter, K. - Frank, W. (1997): The cooling history of the southern Bohemian Massif. J. Czech geol. Soc., 42: 24.

Slabý, J. (1992): Geological map of the Czechoslovakia 1:25000, sheet Dlouhá Stropnice (manuscript). - Czech Geological Survey, Praha.

Staník, E. (1981): Geological map of Czechoslovakia 1:25000, sheet Nové Hrady. ČGÚ Praha

Waldmann, L. (1950): Geologische Spezialkarte der Republik Österreich 1:75000, Blatt Litschau-Gmünd (4454). - Geol. B.-A. Wien.

- (1951): Das außeralpine Grundgebirge Österreichs. In: Schaffer, F. X. (ed): Geologie von Österreich. 2. Aufl., Wien.

\section{Dvojslídné a biotitické granity v okolí Weitry a Nových Hradů (Rakousko, Česká republika)}

Moldanubický pluton se, v tradičním pojetí, sestává ze tří hlavních intruzivních jednotek - weinsberské, eisgarnské a freistadtsko-mauthausenské. Ve skutečnosti je však stavba plutonu mnohem komplikovanejší. V oblasti mezi Weitrou, Novými Hrady a Freistadtem tak byly, kromě zřetelně definovaného weinsberského granitu, nalezeny a na základě geologických, chemických a izotopických dat definovány čtyři další intruzivní jednotky: (1) drobnozrnný místy porfyrický peraluminický dvojslídný granit typu Žofín, $324 \pm 14$ Ma starý s iniciálním izotopickým poměrem $\mathrm{Sr}\left({ }^{87} \mathrm{Sr} /{ }^{86} \mathrm{Sr}\right.$ ) $0.712 ;(2)$ peraluminická frakcionovaná serie hrubozrnného dvojslídného granitu typu Mandelstein a muskovitického granityu od Nakolic-Pyhrabruck a od Šejbů s iniciálním poměrem $\mathrm{Sr}^{87} \mathrm{Sr} /{ }^{86} \mathrm{Sr}_{\mathrm{i}} \sim 0.706$; (3) geochemicky poměrně primitivní biotitický granity typu Karlstift s vysokou magnetickou susceptibilitou a ${ }^{87} \mathrm{Sr}^{86} \mathrm{Sr}_{\mathrm{i}}=$ 0.706 ; (4) biotitický granit typu Weitra s magneticou a nemagnetickou varietou, též následovaný drobnými intruzemi muskovitického granitu ${ }^{87} \mathrm{Sr}^{86} \mathrm{Sr}_{\mathrm{i}}$ 0.705). Vývoj peraluminických granitů směrem k nižším iniciálním poměrům Sr (Žofín〉Mandelstein > Šejby, Nakolice-Pyhrabruck) indikuje změnu ve složení zdrojového materiálu magmat v závěru variského magmatického cyklu.

\section{Appendix}

Whole-rock chemical analyses (Tables 1 and 2) were performed in the laboratory of of the Czech Geological Survey Praha: major-elements determinations were obtained by wet chemistry, trace elements by XRF, rare earth-elements by ICP-OES. Whole-rock Rb-Sr isotope analyses were performed at the Geochronological Laboratory, University Vienna \& Geological Survey of Austria, Wien. See Breiter - Scharbert (1995) for more details.

Rock-forming minerals were analysed using EDS-mode on CamScan microprobe in laboratory of the Czech Geological Survey, Praha; help of A. Gabašová and I. Vavř́n is acknowledged. 